\title{
Kimberley marine biota. Historical data: scleractinian corals
}

\author{
Zoe T. Richards ${ }^{1 *}$, Alison Sampey and Loisette Marsh ${ }^{1}$ \\ ${ }^{1}$ Department of Aquatic Zoology, Western Australian Museum, Locked Bag 49, Welshpool DC \\ Western Australia 6986, Australia.
}

* Email: zoe.richards@museum.wa.gov.au

\begin{abstract}
Limited information is publicly available about the coral fauna of the Kimberley region, particularly of the inshore coastal communities, and this greatly inhibits species conservation efforts. Nevertheless, sporadic coral collection events have occurred in the Kimberley over the last century, so it is important that these historical data are consolidated and made accessible. Biodiversity loss among reef corals poses a significant threat to the function and dynamics of coral reef ecosystems and to the global economy. To maximise the likelihood that coral diversity can be protected in the long term it is imperative that regional biodiversity baselines are established. Here we synthesise the existing records of shallow water $(<30 \mathrm{~m})$ scleractinian coral species in the Kimberley region, which are verified by specimens lodged in Australian museum collections (1880s-2009). Based on 2,420 specimen based records, collected from 70 locations, a total of 338 species of hard corals belonging to 17 families and 71 genera has been identified from Kimberley material. There are pronounced cross shelf differences in species composition with 27 species (8\%) recorded only from inshore locations and 111 species (33\%) recorded only at offshore locations. The inshore Kimberley coral communities are of great regional and national significance for numerous reasons, including their high diversity, inherent tolerance of harsh environmental conditions, and the opportunities they present for examining the biology and ecology of corals in the absence of anthropogenic disturbance.
\end{abstract}

KEYWORDS: baseline data, biodiversity, hard coral, natural history collections, north west Australia, species inventory

\section{INTRODUCTION}

Protected by virtue of its isolation from urban centres and agricultural influences, the Kimberley Project Area (see Methods for boundary explanation) features one of the least impacted marine ecosystems in the world (Halpern et al. 2008). As a result, the Kimberley Project Area is likely to be a significant repository of marine biodiversity. However, to date, restricted information about the coral fauna of the region is publicly available. While substantial baseline information is available about some of the offshore atolls (e.g. Scott and Ashmore Reefs), fauna inhabiting the inshore fringing reefs and coastal habitats, as well as many of the offshore shelf reefs, shoals and banks, remain largely unexplored. The current lack of understanding about the marine fauna in this region precludes targeted conservation effort and further baseline data are needed to fill these knowledge gaps (Waples 2007).

Reefs in the Project Area fall into two distinct groups - the large atolls, platform reefs, banks and shoals that occur in the offshore bioregion, and the fringing and submerged patch reefs that occur in the inshore bioregion (Wilson 2013, 2014). There are 13 atolls in the offshore bioregion (including Scott Reef, Rowley Shoals and Ashmore Reef). The oceanographic setting of the offshore reefs is unique because they occur in a transition zone, receiving low to moderately productive oceanic water of mixed Pacific and Indian Ocean origins. Opposed to this, the inshore communities are uniquely characterised by large tide oscillations $(>11 \mathrm{~m})$, strong currents and high levels of turbidity (Wilson 2006). As a result, inshore reef habitats are extremely dynamic and over spring tides, intertidal coral communities can be directly exposed to harsh temperature and light conditions for up to three hours at a time (Rosser and Veron 2011).

Despite limited information being publicly available concerning the diversity of reef building hard corals in the Kimberley Project Area, sporadic collections have occurred in the region dating back to 1893, when a small collection was obtained from Troughton Island by the British Admiralty 
(described by Bassett-Smith 1899). Admiralty collections, together with specimens collected by W. Saville-Kent from King Sound, the Lacepede Islands and Roebuck Bay, were included in early monographs by Brook (1893), Bernard (1897, 1903, 1905) and Matthai (1928), but these specimens are not deposited in Australian museums.

Substantial collections have been obtained from offshore locations including Mermaid and Clerke Reefs (Rowley Shoals) in 1983 and 2006 (Berry 1986; McKinney 2009), Scott and Seringapatam Reefs in 1984 and 2006 (Veron 1986; McKinney 2009), and Ashmore Reef and Cartier Island in 1986 and 1997 (Veron 1993; Griffith 1997). These coral collections are supplemented by long term coral monitoring projects undertaken by the Australian Institute of Marine Science (AIMS), commissioned by the Australian Government and, in some cases, supported by industry, e.g. Scott Reef (Berry 1986; Smith et al. 2003, 2004, 2006; Gilmour et al. 2008); Rowley Shoals (Berry 1986; McLoughlin et al. 1988; Bryce 2009) and Ashmore Reef and Cartier Island (Berry 1993, 2005; Rees et al. 2003; Smith et al. 2004; Kospartov et al. 2006; Richards et al. 2009).

Collections and publications relating to the coral communities of the inshore coastal bioregion are far fewer in number. Veron and Marsh (1988) recorded 102 species of 45 genera from the Kimberley coast and islands, from material collected from Prince Frederick Harbour, Bigge Island, Admiralty Gulf and Cassini Island. Loisette Marsh collected hard corals at Camden Harbour in 1990 (Marsh 2011) and at various islands and reefs between Broome and Wydham in 1991 (Marsh 1992), and David Blakeway collected corals along the central Kimberley coast in 1996 (Blakeway 1997).

Considering there are over 2,500 islands with well developed fringing reefs along the Kimberley coast (Wilson 2013), the existing collections from this inshore bioregion are comparatively small. Nevertheless, consolidating the existing baseline information is imperative to developing targeted collection and research programs and optimising biodiversity conservation efforts in the future.

\section{AIMS}

To synthesise the existing records of shallow water $(<30 \mathrm{~m})$ hard coral species in the Kimberley Project Area, which are verified by specimens lodged in museum collections (1880s - 2009); and to provide commentary on diversity, regional trends and collection gaps.

\section{METHODS}

The Kimberley Project Area extends west and north of the Kimberley coastline (south of Broome to the Western Australia-Northern Territory border), beyond the $1000 \mathrm{~m}$ bathymetric contour (see Sampey et al. 2014 for map, coordinates and full explanation of the study area).

Skeleton based museum records of shallow water $(<30 \mathrm{~m})$ scleractinian corals belonging to the phylum Cnidaria (class Anthozoa; subclass Hexacorallia) that have been historically collected from the Project Area were collated in this study. Data were sourced from the collection databases of the Western Australian Museum (WAM), the Museum and Art Gallery of the Northern Territory (MAGNT) and the Australian Museum (AM), as well as the species (and locations) documented on five WAM survey expeditions in the Kimberley Project Area in 1982 and 1984 (Veron 1986), 1986 (Veron 1993), 1991 (Marsh 1992), 1996 (Blakeway 1997) and 2006 (McKinney 2009).

The species names were cross checked using Veron and Wallace (1984), Veron (2000), Wallace (1999), Hoeksema (1989) and Cairns (1998) and the classification system reflects Veron (2000), and Wallace (1999) for Acroporidae. The specimens were not re-examined for this study (see Sampey et al. 2014).

Scleractinian coral data from all sources were collated into a single database. Location and collecting details were checked and verified. The location of the specimen records were visualised using ARCGIS v9, ArcMap v9.3. Maps of species richness and sampling effort were generated for each main location. The full list of locations, latitude and longitude and other relevant collection information is provided in Table 2 in Sampey et al. (2014).

\section{BIOGEOGRAPHIC AND HABITAT CODING}

Species were coded for their known biogeographic range and habitat; see Sampey et al. (2014) for a full description of these codes:

- Indo-Australian (IA). From Australian and Indonesian waters, may extend to the Philippines and for some species Japan.

- South East Asia (SE). Restricted to South East Asia.

- Indian Ocean (IO). Restricted to the Indian Ocean.

- Indo-West Pacific (IWP). Found throughout the Red Sea, Indian and W. Pacific Oceans.

- Western Pacific (WP). Found on the East Coast of Australia and Melanesia.

- Indo-Pacific (IP). Found in the Red Sea, Indian Ocean and throughout the Pacific Ocean, in some cases may only extend to the Central Pacific Ocean. 
- Circumglobal (C). Found throughout tropical and temperate waters of the Indian and Pacific Oceans.

- Intertidal (i). Species is found in the intertidal zone.

- Subtidal (s). Species is found in the subtidal zone.

- Hard Substrate (H). Species is found associated with hard substrates (e.g. rock, coral, rubble).

- Soft Substrate (S). Species is found associated with soft substrates (e.g. sand, mud).

In some instances, the species in question does not occur in certain parts of the broad biogeographic zones denoted and these exceptions are described where relevant (i.e. IP, not Australia/ PNG).

\section{RESULTS}

Records from Australian museums indicate a total of 2,700 scleractinian coral specimens were collected from the Project Area between 1889-2009. Two hundred and eighty specimen-based records were excluded from the analysis because they were either obtained from deep reef locations, which are beyond the scope of this project, or because the voucher specimen could not be located. Thus, this study synthesises 2,420 specimen-based records.

Scleractinian skeletal material has been collected from 70 locations in the Project Area originating from six offshore and 65 coastal locations (Figure 1). This material was collected by over 30 people with the most comprehensive collections obtained by L.M. Marsh, J.E.N. Veron, D. McKinney and J.K. Griffith. These four scientists also completed the majority of species identifications, with taxonomic input provided by B. Hoeksema, C.C. Wallace, S.D. Cairns, M. Pichon, P. Alderslade, J. Wells, Z. Dinesen, J. Wolstenholme and L. Thomas.

Over $99 \%$ of the Project Area coral specimens are held at WAM, with small collections held at the AM and the MAGNT. The oldest record from Australian museums for a hard coral collected in the Project Area was Polyphyllia talpina collected from Yampi Sound in 1959.

A total of 338 species of hard corals, belonging to 71 genera and 17 families, has been identified from material collected in the Kimberley Project Area (see Appendix 1). Corals from the families Acroporidae (748 specimens) and Faviidae (560 specimens) are best represented in the collections. There are also substantial collections of corals from the families Poritidae, Fungiidae and Agariciidae (294, 218 and 106 specimens, respectively). To date, 67 species of Acropora, 29 species of Montipora and 15 species of Favia have been identified from the existing collections (Table 1).
The Kimberley Project Area is the type locality of two species (Australomussa rowleyensis and Echinopora ashmorensis) and an additional three species of Acropora were described using specimens collected from within the Project Area, i.e. Acropora loisetteae, Acropora russelli and Acropora indiana, which was subsequently synonymised to $A$. papillare (Wallace, 1999).

Twenty species included in this dataset are denoted with cf. meaning 'compare with'. It is not our intention here to validate or revise the identifications of other taxonomists. However, a number of these records, if deemed correct, would represent important range extensions (e.g. Acropora batunai; Acropora indonesia; Astreopora incrustans). Thus, it will be important in the future to reexamine these specimens in order to validate the occurrence of these species in the Kimberley Project Area.

Excluding those species currently classified as cf., based upon the collection records, five species have been recorded for the first time in Australia (Acropora pichoni, Acanthastrea brevis, Goniopora burgosi, Leptastrea aequalis and Pavona frondifera). The known ranges of an additional seven species have been extended to Western Australia (Acropora echinata, Ctenactis albitentaculata, Cycloseris somervillei, Goniopora palmensis, Halomitra pileus, Porites monticulosa and Scolymia vitiensis).

Collection records suggest at least 310 species are present in the offshore bioregion and at least 225 species occur in the inshore bioregion. Twenty six species $(8 \%)$ are recorded from inshore sites only and 111 species $(33 \%)$ are recorded from the offshore region only (Appendix 2). The overwhelming majority of Acropora were collected from offshore locations (62 species compared to 39 species inshore: Table 2).

Of all the Project Area locations sampled so far, the most comprehensive collection is from Scott Reef, where 268 species have been identified belonging to 14 families (Figure 2). Two hundred and fourteen species from 14 families have been identified from Mermaid Reef and 209 species from 14 families have been collected from Ashmore Reef. Among the inshore locations sampled to date, important but not comprehensive collections have been obtained from One Arm Point (73 species), Scorpion Island (62 species), Cassini Island (61 species), Augustus Island (55 species), Montgomery Reef (53 species) and Churchill Reef (51 species).

At the family level, no locations had all 17 families represented. The greatest family level representation is Scorpion Island, where 15 of the 17 families present in the Project Area are represented in the museum collections. Representatives from a single family have been collected from 13 inshore locations (such as Beagle Bay, Steep Island, Cambridge Gulf, Collier Bay and White Island), 
TABLE 1 Number of species recorded from each genus in the Kimberley Project Area.

\begin{tabular}{|c|c|c|c|}
\hline Genus & No. species & Genus & No. species \\
\hline Acropora & 67 & Lithophyllon & 2 \\
\hline Acanthastrea & 5 & Lobophyllia & 3 \\
\hline Alveopora & 6 & Merulina & 2 \\
\hline Anacropora & 1 & Montastrea & 4 \\
\hline Astreopora & 7 & Montipora & 29 \\
\hline Australomussa & 1 & Moseleya & 1 \\
\hline Barabattoia & 1 & Mycedium & 3 \\
\hline Catalaphyllia & 1 & Oulastrea & 1 \\
\hline Caulastrea & 3 & Oulophyllia & 2 \\
\hline Coeloseris & 1 & Oxypora & 2 \\
\hline Coscinaraea & 3 & Pachyseris & 2 \\
\hline Ctenactis & 3 & Pavona & 10 \\
\hline Cycloseris & 6 & Pectinia & 4 \\
\hline Cynarina & 1 & Physogyra & 1 \\
\hline Cyphastrea & 4 & Platygyra & 7 \\
\hline Diploastrea & 1 & Plerogyra & 1 \\
\hline Duncanopsammia & 1 & Plesiastrea & 1 \\
\hline Echinophyllia & 4 & Pocillopora & 6 \\
\hline Echinopora & 6 & Podabacia & 1 \\
\hline Euphyllia & 3 & Polyphyllia & 1 \\
\hline Favia & 15 & Porites & 14 \\
\hline Favites & 8 & Psammocora & 8 \\
\hline Fungia & 11 & Pseudosiderastrea & 1 \\
\hline Galaxea & 4 & Rhizopsammia & 1 \\
\hline Gardinoseris & 1 & Sandalolitha & 1 \\
\hline Goniastrea & 7 & Scapophyllia & 1 \\
\hline Goniopora & 14 & Scolymia & 1 \\
\hline Halomitra & 1 & Seriatopora & 2 \\
\hline Heliofungia & 1 & Stylocoeniella & 2 \\
\hline Herpolitha & 1 & Stylophora & 1 \\
\hline Heterocyathus & 1 & Symphyllia & 4 \\
\hline Hydnophora & 4 & Trachyphyllia & 1 \\
\hline Isopora & 2 & Truncatoflabellum & 1 \\
\hline Leptastrea & 5 & Tubastrea & 2 \\
\hline Leptoria & 1 & Turbinaria & 8 \\
\hline Leptoseris & 8 & & \\
\hline
\end{tabular}


suggesting they have only been superficially sampled.

All the species recorded from the Project Area have a broad distribution and none are endemic or restricted to the region. The majority of species (74\%) occur in tropical Indo-Pacific locations extending from the Red Sea to the central Pacific Ocean, and an additional $2 \%$ of species are found in both tropical and temperate waters across the Indian and Pacific Oceans. Eighteen percent of species occur in the Indo-West Pacific, 5\% are restricted to South East Asia and $1 \%$ are restricted to the Indo-Australian region. The proportion of globally restricted (IASE-WP) species occurring at offshore versus inshore locations is consistent ( $5 \%$ and $4 \%$ respectively).

Forty one species are recorded from only one site and 30 species are recorded only at a single offshore location. Fifteen species are known only from Scott Reef (Ctenactis albitentaculata, Favia danae, Acropora papillare, Pavona frondifera, Leptoseris glabra, Acropora pichoni, Psammocora obtusangulta, Anacropora puertogalerae, Mycedium manacoi, Galaxea longisepta, Hydnophora pileus, Fungia moluccensis, Cycloseris somervillei, Leptoseris solida and Acropora turaki), six species are recorded only at Ashmore Reef (Tubastrea micranthus, Cycloseris sinensis, Fungia gravis, Acanthastrea bowerbanki, Porites eridani, Porites cf. australiensis), four species are recorded only at Clerke Reef (Euphyllia cristata, Fungia klunzingeri, Alveopora tizardi, Montipora turtlensis), two species are known only from Cartier Reef (Acropora russelli and Echinopora gemmacea) and a single species is known from each of Mermaid Reef (Symphyllia radians) and Seringapatam Reef (Acropora cf. batunai).

Twelve species are recorded at only a single inshore location: Acropora bushyensis (One Arm Point), Acropora dendrum (Powerful Island), Acropora cf. sarmentosa (Scorpion Island), Acropora verweyi (Lord Island), Turbinaria patula (Broome), Favia veroni (Colbert Island), Truncatoflabellum aculeatum (Broome), Echinophyllia echinoporoides (Yankawingarri Island), Goniopora eclipsensis (George Water) and Goniopora cf. norfolkensis (Montgomery Reef).

Seven species have been collected from over 20 locations in the Project Area, indicating they are locally widespread (Fungia fungites, Platygyra sinensis, Platygyra daedalea, Goniastrea retiformis, Goniastrea aspera, Favites abdita and Euphyllia glabrescens). Other species that are well represented in the Project Area collections are Seriatopora hystrix, Galaxea fascicularis, Stylophora pistillata, Lobophyllia hemprichii, Merulina ampliata, Polyphyllia talpina, Herpolitha limax, Porites cylindrica, Goniastrea pectinata, Turbinaria frondens, Pavona decussata and Cyphastrea serailia. While a diversity of species from the genus Acropora have been collected in the Project Area, the existing collections may under-represent their spatial extent.
TABLE 2

Number of species recorded from each genus in the Kimberley Project Area.

\begin{tabular}{|c|c|}
\hline Offshore only & Inshore only \\
\hline Acropora (28 spp.) & Acanthastrea cf. lordhowensis \\
\hline Acanthastrea (2 spp.) & Acanthastrea hillae \\
\hline Alveopora (5 spp.) & Acropora bushyensis \\
\hline Anacropora puertogalerae & Acropora cf. dendrum \\
\hline Astreopora (4 spp.) & Acropora cf. sarmentosa \\
\hline Coscinarea cf. wellsi & Acropora verweyi \\
\hline Ctenactis albitentaculata & Cynarina lacrymalis \\
\hline Cycloseris (4 spp.) & Duncanopsammia axifuga \\
\hline Cyphastrea cf. agassizi & Echinophyllia cf. echinoporoides \\
\hline Echinophyllia echinata & Favia cf. maritima \\
\hline Echinopora (3 spp.) & Favia veroni \\
\hline Euphyllia cristata & Goniastrea australiensis \\
\hline Favia (5 spp.) & Goniopora cf. norfolkensis \\
\hline Favites (2 spp.) & Goniopora eclipsensis \\
\hline Fungia (5 spp.) & Goniopora stokesi \\
\hline Galaxea (2 spp.) & Heterocyathus aequicostatus \\
\hline Goniopora (2 spp.) & Montipora cf. australiensis \\
\hline Leptastrea (2 spp.) & Moseleya latistellata \\
\hline Leptoseris (5 spp.) & Oulastrea crispata \\
\hline Lithophyllon mokai & Pseudosiderastrea tayami \\
\hline Lobophyllia hataii & Scolymia vitiensis \\
\hline Merulina scabricula & Trachyphyllia geoffroyi \\
\hline Montastrea annuligera & Truncatoflabellum aculeatum \\
\hline Montipora (6 spp.) & Tubastrea coccinea \\
\hline Mycedium (2 spp.) & Turbinaria bifrons \\
\hline Pavona (5 spp.) & Turbinaria conspicua \\
\hline Pectinia teres & Turbinaria mesenterina \\
\hline Physogyra lichtensteini & Turbinaria patula \\
\hline \multicolumn{2}{|l|}{ Platygyra ryukyuensis } \\
\hline \multicolumn{2}{|l|}{ Pocillopora (3 spp.) } \\
\hline \multicolumn{2}{|l|}{ Porites (7 spp.) } \\
\hline \multicolumn{2}{|l|}{ Psammocora (2 spp.) } \\
\hline \multicolumn{2}{|l|}{ Stylocoeniella armata } \\
\hline \multicolumn{2}{|l|}{ Symphyllia (2 spp.) } \\
\hline \multicolumn{2}{|l|}{ Tubastrea micranthus } \\
\hline Turbinaria frondens & \\
\hline
\end{tabular}




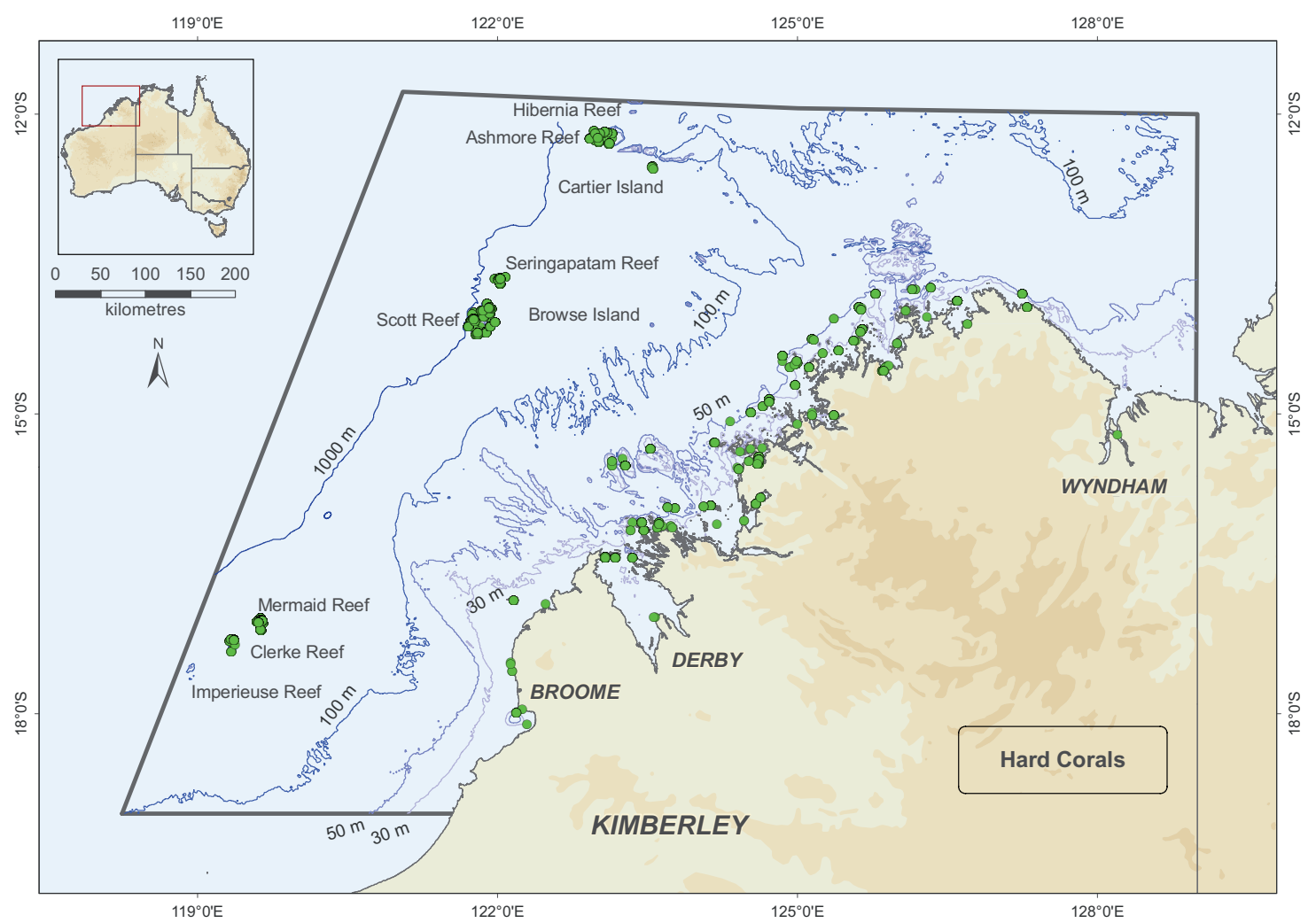

FIGURE 1 Map of the locations where hard corals have been collected historically in the Kimberley Project Area. The Project Area boundary is marked in grey. Map projection: GDA94, Scale: 1:6, 250,000.

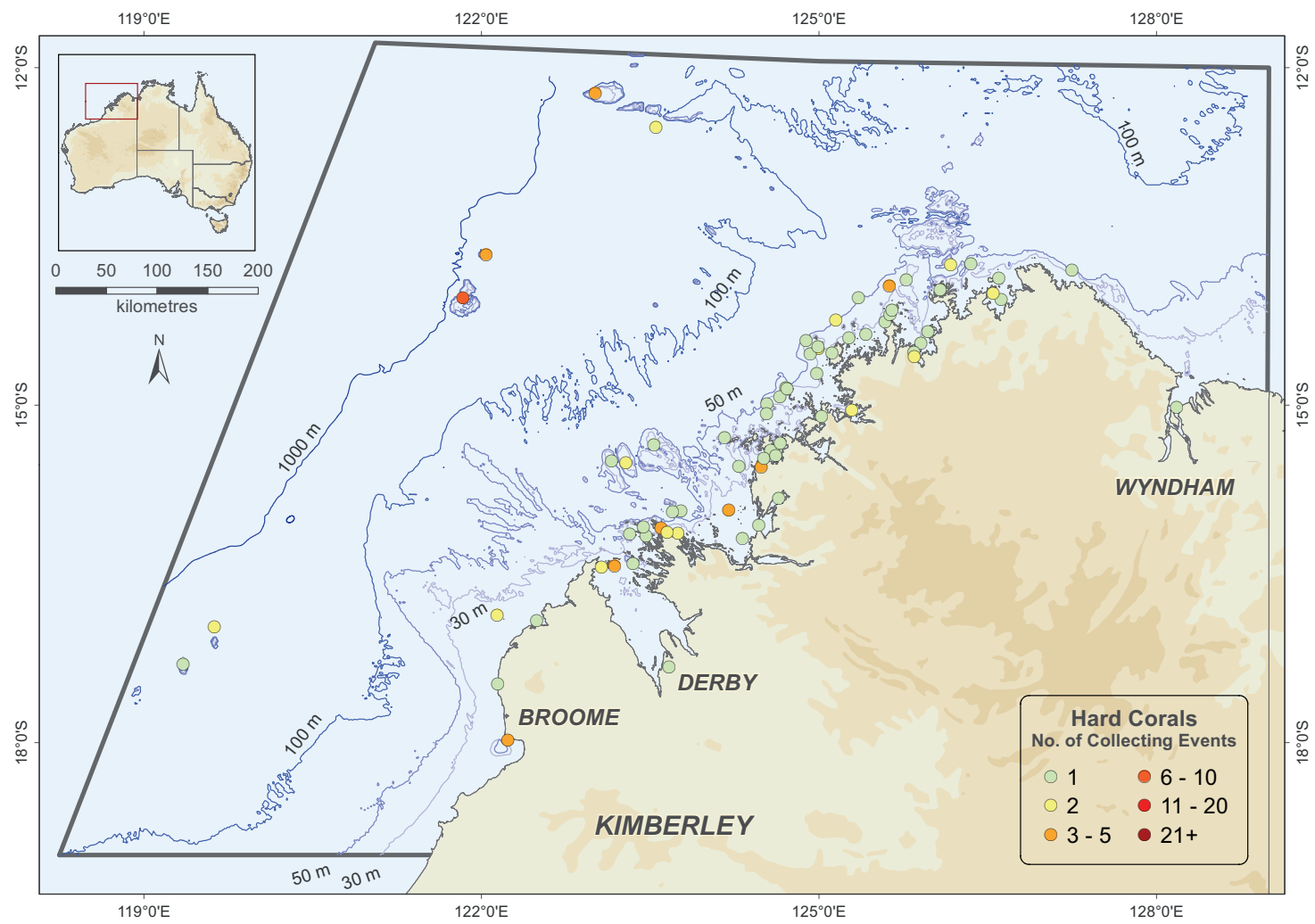

FIGURE 2 The number of collecting events conducted at each sampling location providing a level of sampling effort in the Project Area from 1889-2009. Map projection: GDA94, Scale: 1:6, 250,000. 


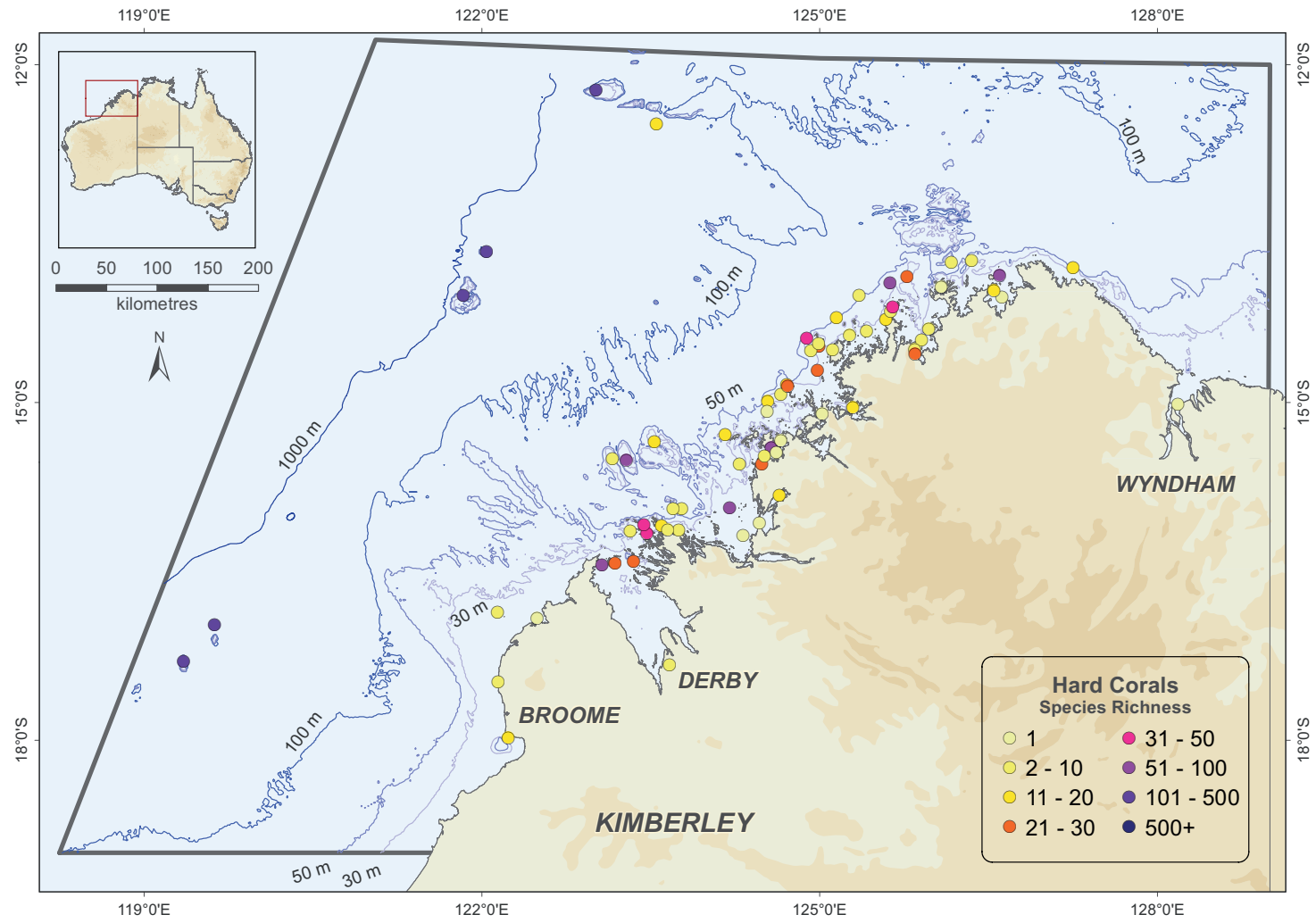

FIGURE 3 The species richness of hard corals in the Project Area based on museum collection records. Map projection: GDA94, Scale: 1:6, 250,000.

\section{DISCUSSION}

This synthesis of the skeleton-based records available for the Kimberley Project Area hard coral fauna indicates at least 338 species of scleractinian corals from 71 genera occur in the Project Area. This level of diversity is the highest recorded in Western Australia and similar to that recorded at the same latitude on the Great Barrier Reef (Devantier et al. 1998, 2006; Wakeford et al. 2008). To date, eight genera present on the Great Barrier Reef are not recorded in collection records from the Project Area (Paulastrea, Madracis, Diaseris, Cantharellus, Heteropsammia, Blastomussa, Australogyra and Stylaraea) and one genus (Australomussa) recorded in the Project Area has not been recorded on the Great Barrier Reef. Among the six offshore atolls and 64 coastal locations sampled to date, Scott Reef has been the most comprehensively studied. Based on current records, almost $79 \%$ of the species known to occur across the Kimberley have been recorded from Scott Reef. Sixteen of the 267 species recorded from Scott Reef (from 14 different genera) have not been recorded at any other location in the Project Area (Figure 3). Furthermore, some of these regionally restricted species have not been recorded anywhere else in
Australia to date (e.g. Acropora pichoni and Pavona frondifera). Scott Reef may be a regional diversity hotspot and, as such, a critical part of the region's coral reef ecosystem. However, this remains to be verified after further targeted biodiversity research is conducted across the wider Kimberley region.

There appears to be pronounced differences in species composition between the inshore and offshore communities of the Project Area, similar to that described from the Great Barrier Reef (Done 1982). Species richness declines from offshore to inshore (309 species offshore versus 225 species inshore). There is only a small area of reef offshore $\left(1,500 \mathrm{~km}^{2}\right)$ and at least three times more reef area inshore, yet the inshore communities support only a subset of the offshore species complement and there is a substantial level of species replacement moving inshore. One hundred and eleven species are recorded only at offshore locations, while 27 species are recorded only at inshore locations (Table 2). Assemblage transitions are particularly evident in the families Acroporidae and Agariciidae. Forty five percent of agaricid species (10 of 22 species) are restricted to offshore locations, whilst $43 \%$ of Acropora species (28 of 67 species) and five of six Alveopora species are only recorded 
offshore. Regional differences in community composition are to be expected, given the offshore and inshore ecosystems are classified within different bioregions and form separate coral reef provinces with very different habitats (Wilson and Allen 1987; Thackway and Cresswell 1998; Wilson et al. 2011; Wilson 2013). The Inshore Coastal Bioregion is defined by its macro-tidal conditions, fringing reefs and muddy rocky shores, while the Oceanic Shoals Bioregion is made up of shelf edge atolls, offshore banks and platform reef with clear water. The offshore reefs are thought to have persisted during glacial maxima and acted as refuges when sea levels were more than $100 \mathrm{~m}$ below present levels. Contrary to this, inshore reefs only date back $\sim 10,000$ years to the Holocene, after the sea level began rising to its present level (Brooke 1997). There is no evidence of Pleistocene reef development (2.5 my-12,000 yBP) in the inshore bioregion and this distinguishes these reefs from those of the Western Pilbara and West Coast Bioregions, where raised Pleistocene limestone benches and fossil reefs are well developed (Brooke 1995; Wilson 2013, 2014).

Differences in the assemblages of coral communities offshore versus inshore are also likely to be driven by physical processes and water clarity (Fabricius et al. 2005). On the east coast of Australia, the species richness of hard corals declines in association with increasing turbidity and chlorophyll (De'ath and Fabricius 2010). In the Kimberley, large diurnal tides, strong currents and the shallow bathymetry of the inshore habitats lead to high water movement and variable levels of turbidity. As the tide cycles, particulate matter is deposited and re-suspended as it is slowly transported westwards by the surface flowing South Equatorial Current, which introduces low salinity water from the Pacific into the Indian Ocean via the Timor Sea (Wyrtki 1987). Furthermore, the inshore communities must withstand additional abiotic stressors, including low tide emersion, fluctuating temperature, sun and wind conditions, physical damage from stormgenerated waves and freshwater inundation (Glynn 1976; Dunne and Browne 1991).

Dynamic environmental conditions can be stressful for scleractinian corals (Philipp and Fabricius 2003). Hence, it is expected that in the Kimberley a particular suite of inshore species would be found, which are adapted to these dynamic conditions. Indeed, the collection records indicate species that are hardy and sediment/ nutrient or thermo-tolerant, such as species within the genus Turbinaria (Done 1982; StaffordSmith and Ormond 1992; Philipp and Fabricius 2003), reach their highest diversity inshore. In addition, other solitary and/or free-living species such as Trachyphyllia geoffreyi, Truncatoflabellum aculeatum, Heterocyathus aequicostatus, Moseleya latistellata, Cynarina lacrymalis and Scolymia vitiensis, which often live on soft substrata, are also only recorded inshore. The comparatively low diversity of Acropora in the inshore bioregion may be a reflection that Acropora do not survive well under these harsh environmental conditions. However, additional surveys are required to confirm this.

While corals were traditionally thought to prefer clear water because light penetration benefits photosynthesis (i.e. autotrophy by their symbiotic dinoflagellates), it is now understood that at high particle loads, some corals gain energy by increasing their heterotrophic feeding, i.e. using their tentacles to capture food from the water column (Anthony and Fabricius 2000). Hence, corals growing in the Kimberley inshore bioregion may offset the stress and low photosynthetic output accompanying high turbidity by changing their trophic mode and this sustains a positive energy balance in turbid conditions. However, while adult corals can potentially adapt to the turbid conditions (Stafford-Smith and Ormond 1992), early life stages are particularly sensitive and both coral settlement and juvenile survival are inhibited by sedimentation, especially where sediments are organically enriched (Fabricius et al. 2003).

The data presented here expand our knowledge of the range of coral biodiversity present in the Kimberley Project Area and will help support species conservation in the region. It is important to note that the historical collection records presented here may not accurately reflect the composition of contemporary assemblages. For example, a rapid visual assessment of scleractinian species richness at Mermaid, Scott and Seringapatam Reefs (McKinney 2009) reported lower numbers of species at these locations than implied by the historical records. Similarly, the most recent quantification of coral biodiversity at Ashmore and Cartier Reefs (Richards et al. 2009) reported a lower number of coral species than historical records indicate. Taxonomic inconsistency may help explain some of the differences in the contemporary and historical datasets. However, it is also probable that some species turnover has occurred throughout the region and it is rare for the entire species assemblage to be detected on a single survey.

In natural communities, species turnover occurs as a result of natural stochasticity and patch dynamics (Wu and Loucks 1995; Levin 2002), both are influenced by disturbance (Wakeford et al. 2008). Reefs in the Project Area offshore region experienced severe bleaching in 1998 and 2003. At Scott Reef, bleaching led to approximately $80 \%$ of coral cover being lost and after six years of recovery, an obvious shift in community structure had taken place (Smith et al. 2008). Most notably, there was a 
decline in the relative abundance of the previously dominant reef building coral family Acroporidae and relative increases of massive corals within the families Poritidae and Faviidae (Smith et al. 2008). After 12 years, coral cover, recruitment, generic diversity and community structure were similar to those observed pre-bleaching (Gilmour et al. 2013). Similarly, at Ashmore Reef changes in community structure have been documented over the last decade (Ceccarelli et al. 2011).

In order to better understand how the coral communities within the Kimberley Project Area are structured and to detect temporal changes, empirical ecological data are needed. For this reason, from 2009-2013 standardised and replicated quantitative abundance data on coral biodiversity have been collected on belt transects at over 140 stations spanning inshore, midshelf and offshore Kimberley locations (including Adele Island, Ashmore Reef, Browse Island, Champagney Islands, Cassini Island, Hibernia Reef, Long Reef, Montalivet Island, Montgomery Reef, Robroy Reefs, White Island and Wildcat Reefs) and various mid-shelf shoals, as part of the WAM Kimberley Woodside Collection Project (Richards in preparation). Preliminary results from these surveys indicate a large amount of spatial variability in species richness across the inshore coral communities, but that certain locations have exceptionally high coral diversity (e.g. Cassini Island). Further taxonomic studies, coupled with ecological analyses will provide important insights into how these communities are structured and give a clearer picture of how coral diversity varies spatially in the Kimberley Project Area.

A number of the species in this study require further examination in conjunction with the new material collected in the WAM Kimberley Woodside Collection Project. As a consequence the total species number from the region will be higher than that reported here. Furthermore, hundreds of locations in the Project Area have not been surveyed previously, including Imperieuse Reef and Holothuria Banks, and other inshore locations such as Beagle Bay, Steep Island, Cambridge Gulf, Collier Bay and Scorpion Island, which have been only superficially surveyed. It will also be important to survey the coral communities living in the nearshore and mangrove habitats, inter-reefal areas and coastal soft bottom habitats, which have received comparatively little collection effort.

The coral community within the Project Area is of great national and international significance for three important reasons. Firstly, our compilation of historical data suggests there is a high level of coral diversity in this region. Secondly, the hardy Kimberley coastal coral communities may be indicative of those species and genotypes best suited to future conditions on coral reefs (including increasing water temperature and turbidity). Lastly, the Project Area provides some of the least impacted coral reef habitat in the world. With this comes an opportunity to examine how communities are structured across environmental gradients in the absence of anthropogenic disturbance. Continuing to develop and expand research programs concerning corals within the Project Area is of profound interest to coral science and coral reef conservation.

\section{ACKNOWLEDGEMENTS}

Thanks to our colleagues, Charlie Veron, Jane Griffiths and David McKinney who collected and identified most of the coral specimens contained in this dataset. Thanks to Stacey Osborne and Albert Miles for databasing the unregistered Kimberley material in the WAM collections and for checking taxonomic and spatial information, and to Stacey Osborne for assistance in formatting the tables.

\section{REFERENCES}

Anthony, K.R.N. and Fabricius, K.E. (2000). Shifting roles of heterotrophy and autotrophy in coral energetics under varying turbidity. Journal of Experimental Marine Biology and Ecology 252: 221-253.

Bassett-Smith, P.W. (1899). On the formation of the coralreefs on the NW coast of Australia. Proceedings of the Zoological Society of London 67: 157-159.

Bernard, H.M. (1897). The genus Montipora. Catalogue of the madreporarian corals in the British Museum (Natural History) 3.

Bernard, H.M. (1903). The family Poritidae, I. The genus Goniopora. Catalogue of the madreporarian corals in the British Museum (Natural History) 4: 1-166.

Bernard, H.M. (1905). The family Poritidae, II. The genus Porites. Porites of the Indo-Pacific region. Catalogue of the madreporarian corals in the British Museum (Natural History) 5: 1-202.

Berry, P.F. (ed.) (1986). Faunal surveys of the Rowley Shoals, Scott Reef and Seringapatam Reef, northwestern Australia. Records of the Western Australian Museum Supplement 25: 1-25.

Berry, P.F. (ed.) (1993). Marine faunal surveys of Ashmore Reef and Cartier Island, north-western Australia. Records of the Western Australian Museum, Supplement 44.

Blakeway, D. (1997). Part 9. Scleractinian corals and reef development (pp. 77-85). In: Walker, D.I. (ed.). Marine biological survey of the central Kimberley coast, Western Australia. University of Western Australia: Perth. Unpublished report.

Brook, G. (1893). The genus Madrepora. Catalogue of the madreporarian corals in the British Museum (Natural History) 1: 1-212.

Brooke, B. (1995). Geomorphology (pp. 21-51). In: Wells, F.E., Hanley, J.R. and Walker, D.I. (eds). Marine biological survey of the southern Kimberley, Western 
Australia. Western Australian Museum: Perth. Unpublished report.

Brooke, B. (1997). Geomorphology of the islands and inner shelf reefs of the central Kimberley coast (pp. 13-39). In: Walker, D. (ed.). Marine biological survey of the central Kimberley coast, Western Australia. University of Western Australia: Perth. Unpublished report.

Bryce, C.W. (ed.) (2009). Marine biodiversity survey of Mermaid (Rowley Shoals), Scott and Seringapatam Reefs. Records of the Western Australian Museum Supplement 77.

Cairns, S.D. (1998). Azooxanthellate Scleractinia (Cnidaria: Anthozoa) of Western Australia. Records of the Australian Museum 18: 361-417.

Ceccarelli, D., Richards, Z.T., Pratchett, M. and Citanovic, C. (2011). Rapid increases in coral cover on an isolated coral reef, the Ashmore Reef National Nature Reserve, north-western Australia. Marine and Freshwater Research 62: 1-7.

De'ath, G. and Fabricius, K. (2010). Water quality as a regional driver of coral biodiversity and macroalgae on the Great Barrier Reef. Ecological Applications 20: 840-850.

Devantier, L.M., De'ath, G., Done, T.J. and Turak, E. (1998). Ecological assessment of a complex natural system: a case study from the Great Barrier Reef. Ecological Applications 8: 480-496.

DeVantier, L.M., De'ath, G., Turak, E., Done, T.J. and Fabricius, K.E. (2006). Species richness and community structure of reef-building corals on the nearshore Great Barrier Reef. Coral Reefs 25: 329-340.

Done, T.J. (1982). Patterns in the distribution of coral communities across the central Great Barrier Reef. Coral Reefs 1: 95-107.

Dunne, R.P. and Brown, B.E. (2001). The influence of solar radiation on bleaching of shallow water reef corals in the Andaman Sea, 1993-1998. Coral Reefs 20: 201-210.

Fabricius, K., Wild, C., Wolanski, E. and Abele, D. (2003). Effects of transparent exopolymer particles (TEP) and muddy terrigenous sediments on the survival of hard coral recruits. Estuarine, Coastal and Shelf Science 57: 613-621.

Fabricius, K., De'ath, G., McCook, L., Turak, E. and McWilliams, D. (2005). Changes in algal, coral and fish assemblages along water quality gradients on the inshore Great Barrier Reef. Marine Pollution Bulletin 51: 384-398.

Gilmour, J.P., Travers, M.J., Underwood, J.N., McKinney, D.W., Gates, E.N., Birrell, C.L. and Fitzgerald, K.L. (2008). The status of shallow-water coral and fish communities at Scott Reef. Australian Institute of Marine Science: Perth.

Gilmour, J.P., Smith, L.D., Heyward, A.J., Baird, A.H. and Pratchett, M.S. (2013). Recovery of an isolated coral reef system following severe disturbance. Science $\mathbf{3 4 0 :}$ 69-71.

Glynn, P.W. (1976). Some physical and biological determinants of coral community structure in the eastern Pacific. Ecological Monographs 46: 431-456.

Griffith, J.K. (1997). The corals collected during September/ October 1997 at Ashmore Reef, Timor Sea. West Australian Museum: Perth. Unpublished report.

Halpern, B.S. Walbridge, S., Selkoe, K.A., Kappel, C.V.,
Micheli, F., D'Agrosa, C., Bruno, J.F., Casey, K.S., Ebert, C., Fox, H.E., Fujita, R., Heinemann, D., Lenihan, H.S., Madin, E.M.P., Perry, M.T., Selig, E.R., Spalding, M., Steneck, R. and Watson, R. (2008). A global map of human impact on marine ecosystems. Science 319: 948-952.

Hoeksema, B.W. (1989). Taxonomy, phylogeny and biogeography of mushroom corals (Scleractinia: Fungiidae). Zoologische Verhandligen Leiden 252: 1-295.

Kospartov, M., Beger, M., Ceccarelli, D. and Richards, Z. (2006). An assessment of the distribution and abundance of sea cucumbers, trochus, giant clams, coral, fish and invasive marine species at Ashmore Reef National Nature Reserve and Cartier Island Marine Reserve. Unpublished Uniquest report to the Department of the Environment, Heritage, Water and the Arts: Canberra.

Levin, S.A. (2002). The problem of pattern and scale in ecology: The Robert H. MacArthur Award Lecture. Ecology 73: 1943-1967.

Marsh, L.M. (1992). Part II. Scleractinian and other hard corals (pp. 15-22). In: Morgan, G.J. (ed.). Survey of the Aquatic Fauna of the Kimberley islands and reefs, Western Australia. Western Australian Museum: Perth. Unpublished Report.

Marsh, L.M. (2011). The 1990 expedition to Camden Harbour, north-west Kimberley: Part 5- marine invertebrates. The Western Australian Naturalist 27: 268-277.

Matthai, G. (1928). A monograph of the recent meandroid Astraeidae. Catalogue on the madreporarian corals. 7: 1-288. British Museum (Natural History): London.

McKinney, D. (2009). A survey of the scleractinian corals at Mermaid, Scott and Seringapatam Reefs, Western Australia (pp. 105-144). In: Bryce, C.W. (ed.) (2009). Marine biodiversity survey of Mermaid Reef (Rowley Shoals), Scott and Seringapatam Reef. Records of the Western Australian Museum Supplement 77.

McLoughlin, R.J., Davis, T.L.O. and Ward, T.J. (1988). Sedimentary provinces, and associated bedforms and benthos on the Scott Reef-Rowley Shoals platform off north-west Australia. Marine and Freshwater Research 39(2): 133-144.

Philipp, E. and Fabricius, K. (2003). Photophysiological stress in scleractinian corals in response to short-term sedimentation. Journal of Experimental Marine Biology and Ecology 287: 57-78.

Rees, M., Colquhoun, J., Smith, L. and Heyward, A. (2003). Surveys of Trochus, Holothuria, giant clams and the coral communities at Ashmore Reef, Cartier Reef and Mermaid Reef, north Western Australia. Australian Institute of Marine Science: Townsville.

Richards, Z., Beger, M., Hobbs, J-P., Bowling, T., ChongSeng, K. and Pratchett, M. (2009). Ashmore Reef National Nature Reserve and Cartier Island Marine Reserve marine survey 2009. ARC Centre of Excellence for Coral Reef Studies. Produced for the Department of the Environment, Water, Heritage and the Arts.

Rosser, N.L. and Veron, J.E.N. (2011). Australian corals thriving out of water in an extreme environment. Coral Reefs 30: 21.

Sampey, A., Bryce, C., Osborne, S., Miles, A. (2014). Kimberley marine biota. Historical data: introduction and methods. Records of the Western Australian Museum Supplement 84: 19-43. 
Smith, L., Gilmour, J. and Heyward, A. (2003). Biological and physical environment at Scott Reef: 1994-2003, II: Biological Environment. Australian Institute of Marine Science: Perth.

Smith, L., Gilmour, J., Rees, M., Lough, J., Halford, A., Underwood, J., van Oppen, M. and Heyward, A. (2004). Biological and physical environment at Scott Reef: 2003 to 2004. III Biological Environment. Report for Woodside Energy Ltd. Australian Institute of Marine Science: Perth.

Smith, L., McAllister, F., Rees, M., Colquhoun, J. and Gilmour, J. (2006). Benthic habitat survey of Scott Reef $(0-60 m)$. Australian Institute of Marine Science: Perth.

Smith, L., Gilmour, J.P. and Heyward, A.J. (2008). Resilience of coral communities on an isolated system of reefs following catastrophic mass-bleaching. Coral Reefs 27: 197-205.

Stafford-Smith, M.G. and Ormond, R.F.G. (1992). Sediment-rejection mechanisms of 42 species of Australian scleractinian corals. Australian Journal of Marine and Freshwater Research 43: 683-705.

Thackway, R. and Cresswell, I.D. (1998). Interim marine and coastal regionalisation for Australian ecosystem based classification for marine and coastal environments. Environment Australia, Commonwealth Department of Environment: Canberra.

Veron, J.E.N. (1986). Part II: Reef-building corals. Records of the Western Australian Museum Supplement 25: 27-36.

Veron, J.E.N. (1993). Part 2. Hermatypic corals of Ashmore Reef and Cartier Island. Records of the Western Australian Museum Supplement 44: 13-20.

Veron, J.E.N. (2000). Corals of the World. Volumes 1-3. Australian Institute of Marine Science.

Veron, J.E.N. and Marsh, L.M. (1988). Hermatypic corals of Western Australia. Records and annotated species list. Records of the Western Australian Museum Supplement 29: 1-16.

Veron, J. and Wallace, C.C. (1984). Scleractinia of Eastern Australia. Part V. Family Acroporidae. Australian
Institute of Marine Science Monograph Series. Australian Government Publishing Service: Canberra.

Wakeford, M., Done, T.J. and Johnson, C.R. (2008). Decadal trends in a coral community and evidence of changed disturbance regime. Coral Reefs 27: 1-13.

Wallace, C. (1999). Staghorn corals of the world: A revision of the genus Acropora. CSIRO Publishing: Melbourne.

Waples, K. (2007). Kimberley Biodiversity Review. EPA Services Unit and the Environmental Management Branch, Department of Environment and Conservation: Perth.

Wilson, B.R. and Allen, G.A. (1987). Major components and distribution of marine fauna (pp. 43-68). In: Dyne, G.R. and Walton, D.W. (eds). The fauna of Australia. General articles. Australian Government Publishing Service: Canberra.

Wilson, B. (2006). Coastal marine habitats, flora and fauna of the Kimberley Region. Unpublished report to INPEX.

Wilson, B. (2013). The Biogeography of the Australian North West Shelf: Environmental Change and Life's Response. Elsevier: Waltham, U.S.A.

Wilson, B.R. (2014). Kimberley marine biota: historical and environmental introduction. Records of the Western Australian Museum Supplement 84: 1-18.

Wilson, B., Blake, S., Ryan, D. and Hacker, J. (2011). Reconnaissance of species-rich coral reefs in a muddy, macro-tidal, enclosed embayment, Talbot Bay, Kimberley, Western Australia. Journal of the Royal Society of Western Australia 94: 251-265.

Wyrtki, K. (1987). Indonesian Through Flow and the associated pressure gradient. Journal of Geophysical Research 92: 941-946.

$\mathrm{Wu}, \mathrm{J}$. and Loucks, O.L. (1995). From balance of nature to hierarchical patch dynamics: A paradigm shift in ecology. The Quarterly Review of Biology 70: 439-466.

MANUSCRIPT RECEIVED 27 JUNE 2013; ACCEPTED 12 SEPTEMBER 2014 
APPENDIX 1 Species collected from the Kimberley Project Area (1959-2009) based on voucher specimens deposited in Australian museums.

\begin{tabular}{|c|c|c|c|}
\hline Taxa & Habitat code & Biogeographic code & \\
\hline \multicolumn{4}{|l|}{ Family: Acroporidae } \\
\hline Acropora abrolhosensis Veron, 1985 & $\mathrm{H}^{\mathrm{s}}$ & IWP & \\
\hline Acropora abrotanoides (Lamarck, 1816) & $\mathrm{H}^{\mathrm{s}}$ & IP & \\
\hline Acropora aculeus (Dana, 1846) & $\mathrm{H}^{\mathrm{s}}$ & IP & - \\
\hline Acropora acuminata (Verrill, 1864) & $\mathrm{H}^{\mathrm{s}}$ & IP & \\
\hline Acropora anthocercis (Brook, 1893) & $\mathrm{H}^{\mathrm{s}}$ & IP & $\bullet$ \\
\hline Acropora aspera (Dana, 1846) & $\mathrm{H}^{\mathrm{s}}$ & IP & $\bullet$ \\
\hline Acropora austera (Dana, 1846) & $\mathrm{H}^{\mathrm{s}}$ & IP & $\bullet$ \\
\hline Acropora cf. batunai Wallace, 1997 & $\mathrm{H}^{\mathrm{s}}$ & SE & \\
\hline Acropora cf. bushyensis Veron \& Wallace, 1984 & $\mathrm{H}^{\mathrm{s}}$ & IA & $\bullet$ \\
\hline Acropora carduus (Dana, 1846) & $\mathrm{H}^{\mathrm{s}}$ & IP & \\
\hline Acropora caroliniana Nemenzo, 1976 & $\mathrm{H}^{\mathrm{s}}$ & IWP & \\
\hline Acropora cerealis (Dana, 1846) & $\mathrm{H}^{\mathrm{s}}$ & IP & $\bullet$ \\
\hline Acropora clathrata (Brook, 1891) & $\mathrm{H}^{\mathrm{s}}$ & IP & - \\
\hline Acropora cytherea (Dana, 1846) & $\mathrm{H}^{\mathrm{s}}$ & IP & $\bullet$ \\
\hline Acropora cf. dendrum (Bassett-Smith, 1890) & $\mathrm{H}^{\mathrm{s}}$ & IWP & $\bullet$ \\
\hline Acropora cf. desalwii Wallace, 1994 & $\mathrm{H}^{\mathrm{s}}$ & SE & \\
\hline Acropora digitifera (Dana, 1846) & $\mathrm{H}^{\mathrm{s}}$ & IP & - \\
\hline Acropora divaricata (Dana, 1846) & $\mathrm{H}^{\mathrm{s}}$ & IP & $\bullet$ \\
\hline Acropora donei Veron \& Wallace, 1984 & $\mathrm{H}^{\mathrm{s}}$ & IP & \\
\hline Acropora echinata (Dana, 1846) & $\mathrm{H}^{\mathrm{s}}$ & IP & \\
\hline Acropora elseyi (Brook, 1892) & $\mathrm{H}^{\mathrm{s}}$ & IP & \\
\hline Acropora exquisita Nemenzo, 1971 & $\mathrm{H}^{\mathrm{s}}$ & IWP & \\
\hline Acropora florida (Dana, 1846) & $\mathrm{H}^{\mathrm{s}}$ & IP & $\bullet$ \\
\hline Acropora gemmifera (Brook, 1892) & $\mathrm{H}^{\mathrm{s}}$ & IP & $\bullet$ \\
\hline Acropora glauca (Brook, 1893) & $\mathrm{H}^{\mathrm{s}}$ & IP & \\
\hline Acropora grandis (Brook, 1892) & $\mathrm{H}^{\mathrm{s}}$ & IP & \\
\hline Acropora granulosa (Milne Edwards \& Haime, 1860) & $\mathrm{H}^{\mathrm{s}}$ & IP & \\
\hline Acropora horrida (Dana, 1846) & $\mathrm{H}^{\mathrm{s}}$ & IP & $\bullet$ \\
\hline Acropora humilis (Dana, 1846) & $\mathrm{H}^{\mathrm{s}}$ & IP & - \\
\hline Acropora hyacinthus (Dana, 1846) & $\mathrm{H}^{\mathrm{s}}$ & IP & - \\
\hline Acropora cf. indonesia Wallace, 1997 & $\mathrm{H}^{\mathrm{s}}$ & SE & \\
\hline Acropora intermedia (Brook, 1891) & $\mathrm{H}^{\mathrm{s}}$ & IP & - \\
\hline Acropora latistella (Brook, 1891) & $\mathrm{H}^{\mathrm{s}}$ & IP & $\bullet$ \\
\hline Acropora listeri (Brook, 1893) & $\mathrm{H}^{\mathrm{s}}$ & IP & \\
\hline Acropora loisetteae Wallace, 1994 & $\mathrm{H}^{\mathrm{s}}$ & IWP & \\
\hline Acropora longicyathus (Milne Edwards \& Haime, 1860) & $\mathrm{H}^{\mathrm{s}}$ & IP & \\
\hline Acropora loripes (Brook, 1892) & $\mathrm{H}^{\mathrm{s}}$ & IP & \\
\hline Acropora lutkeni Crossland, 1952 & $\mathrm{H}^{\mathrm{s}}$ & IP & $\bullet$ \\
\hline Acropora microclados (Ehrenberg, 1834) & $\mathrm{H}^{\mathrm{s}}$ & IP & - \\
\hline Acropora microphthalma (Verrill, 1869) & $\mathrm{H}^{\mathrm{s}}$ & IP & $\bullet$ \\
\hline Acropora millepora (Ehrenberg, 1834) & $\mathrm{H}^{\mathrm{s}}$ & IP & $\bullet$ \\
\hline Acropora monticulosa (Brüggemann, 1879) & $\mathrm{H}^{\mathrm{s}}$ & IP & \\
\hline Acropora muricata (Linnaeus, 1758) & $\mathrm{H}^{\mathrm{s}}$ & IP & - \\
\hline Acropora nana (Studer, 1878) & $\mathrm{H}^{\mathrm{s}}$ & IP & - \\
\hline Acropora nasuta (Dana, 1846) & $\mathrm{H}^{\mathrm{s}}$ & IP & \\
\hline
\end{tabular}




\begin{tabular}{|c|c|c|c|}
\hline Taxa & Habitat code & Biogeographic code & $\begin{array}{l}\text { 며 } \\
\text { 드 } \\
\text { ఏ }\end{array}$ \\
\hline Acropora paniculata Verrill, 1902 & $\mathrm{H}^{\mathrm{s}}$ & IP & $\bullet$ \\
\hline Acropora papillare Latypov, 1992 & $\mathrm{H}^{\mathrm{s}}$ & IWP & \\
\hline Acropora pichoni Wallace, 1999 & $\mathrm{H}^{\mathrm{s}}$ & IWP & \\
\hline Acropora polystoma (Brook, 1891) & $\mathrm{H}^{\mathrm{s}}$ & IP & \\
\hline Acropora pulchra (Brook, 1891) & $\mathrm{H}^{\mathrm{s}}$ & IP & $\bullet$ \\
\hline Acropora robusta (Dana, 1846) & $\mathrm{H}^{\mathrm{s}}$ & IP & $\bullet$ \\
\hline Acropora russelli Wallace, 1994 & $\mathrm{H}^{\mathrm{s}}$ & IA & \\
\hline Acropora samoensis (Brook, 1891) & $\mathrm{H}^{\mathrm{s}}$ & IP & $\bullet$ \\
\hline Acropora cf. sarmentosa (Brook, 1892) & $\mathrm{H}^{\mathrm{s}}$ & IP & $\bullet$ \\
\hline Acropora secale (Studer, 1878) & $\mathrm{H}^{\mathrm{s}}$ & IP & \\
\hline Acropora selago (Studer, 1878) & $\mathrm{H}^{\mathrm{s}}$ & IP & $\bullet$ \\
\hline Acropora solitaryensis Veron \& Wallace, 1984 & $\mathrm{H}^{\mathrm{s}}$ & IP & $\bullet$ \\
\hline Acropora spicifera (Dana, 1846) & $\mathrm{H}^{\mathrm{s}}$ & IP & $\bullet$ \\
\hline Acropora subglabra (Brook, 1891) & $\mathrm{H}^{\mathrm{s}}$ & IWP & \\
\hline Acropora subulata (Dana, 1846) & $\mathrm{H}^{\mathrm{s}}$ & IP & • \\
\hline Acropora tenuis (Dana, 1846) & $\mathrm{H}^{\mathrm{s}}$ & IP & • \\
\hline Acropora turaki Wallace, 1994 & $\mathrm{H}^{\mathrm{s}}$ & IWP & \\
\hline Acropora valenciennesi (Milne Edwards \& Haime, 1860) & $\mathrm{H}^{\mathrm{s}}$ & IP & $\bullet$ \\
\hline Acropora valida (Dana, 1846) & $\mathrm{H}^{\mathrm{s}}$ & IP & $\bullet$ \\
\hline Acropora vaughani Wells, 1954 & $\mathrm{H}^{\mathrm{s}}$ & IP & $\bullet$ \\
\hline Acropora verweyi Veron \& Wallace, 1984 & $\mathrm{H}^{\mathrm{s}}$ & IP & $\bullet$ \\
\hline Acropora yongei Veron \& Wallace, 1984 & $\mathrm{H}^{\mathrm{s}}$ & IP & $\bullet$ \\
\hline Anacropora puertogalerae Nemenzo, 1964 & $\mathrm{H}^{\mathrm{s}}$ & IWP & \\
\hline Astreopora cf. cucullata Lamberts, 1980 & $\mathrm{H}^{\mathrm{s}}$ & IP & \\
\hline Astreopora expansa Brüggemann, 1877 & $\mathrm{H}^{\mathrm{s}}$ & IP & \\
\hline Astreopora gracilis Bernard, 1896 & $\mathrm{H}^{\mathrm{s}}$ & IP & $\bullet$ \\
\hline Astreopora cf. incrustans Bernard, 1896 & $\mathrm{H}^{\mathrm{s}}$ & IWP & \\
\hline Astreopora cf. listeri Bernard, 1896 & $\mathrm{H}^{\mathrm{s}}$ & $\mathrm{IP}$ & \\
\hline Astreopora myriophthalma (Lamarck, 1816) & $\mathrm{H}^{\mathrm{s}}$ & IP & $\bullet$ \\
\hline Astreopora ocellata Bernard, 1896 & $\mathrm{H}^{\mathrm{s}}$ & IP & $\bullet$ \\
\hline Isopora brueggemanni (Brook, 1893) & $\mathrm{H}^{\mathrm{s}}$ & IP & $\bullet$ \\
\hline Isopora palifera (Lamarck, 1816) & $\mathrm{H}^{\mathrm{s}}$ & IP & $\bullet$ \\
\hline Montipora aequituberculata Bernard, 1897 & $\mathrm{H}^{\mathrm{s}}$ & IP & $\bullet$ \\
\hline Montipora angulata (Lamarck, 1816) & $\mathrm{H}^{\mathrm{s}}$ & IP & $\bullet$ \\
\hline Montipora cf. australiensis Bernard, 1897 & $\mathrm{H}^{\mathrm{s}}$ & IP & $\bullet$ \\
\hline Montipora caliculata (Dana, 1846) & $\mathrm{H}^{\mathrm{s}}$ & $\mathrm{IP}$ & $\bullet$ \\
\hline Montipora crassituberculata Bernard, 1897 & $\mathrm{H}^{\mathrm{s}}$ & IP & $\bullet$ \\
\hline Montipora danae (Milne Edwards \& Haime, 1851) & $\mathrm{H}^{\mathrm{s}}$ & IP & $\bullet$ \\
\hline Montipora digitata (Dana, 1846) & $\mathrm{H}^{\mathrm{s}}$ & IP & $\bullet$ \\
\hline Montipora efflorescens Bernard, 1897 & $\mathrm{H}^{\mathrm{s}}$ & IP & $\bullet$ \\
\hline Montipora floweri Wells, 1954 & $\mathrm{H}^{\mathrm{s}}$ & IP & \\
\hline Montipora foliosa (Pallas, 1766) & $\mathrm{H}^{\mathrm{s}}$ & IP & \\
\hline Montipora foveolata (Dana, 1846) & $\mathrm{H}^{\mathrm{s}}$ & IP & • \\
\hline Montipora grisea Bernard, 1897 & $\mathrm{H}^{\mathrm{s}}$ & IP & $\bullet$ \\
\hline Montipora hispida (Dana, 1846) & $\mathrm{H}^{\mathrm{s}}$ & IP & $\bullet$ \\
\hline Montipora hoffmeisteri Wells, 1954 & $\mathrm{H}^{\mathrm{s}}$ & IP & \\
\hline Montipora incrassata (Dana, 1846) & $\mathrm{H}^{\mathrm{s}}$ & IP & \\
\hline Montipora informis Bernard, 1897 & $\mathrm{H}^{\mathrm{s}}$ & IP & $\bullet$ \\
\hline
\end{tabular}




\begin{tabular}{|c|c|c|c|}
\hline Taxa & Habitat code & Biogeographic code & 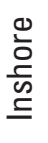 \\
\hline Montipora millepora Crossland, 1952 & $\mathrm{H}^{\mathrm{s}}$ & IP & $\bullet$ \\
\hline Montipora mollis Bernard, 1897 & $\mathrm{H}^{\mathrm{s}}$ & IP & $\bullet$ \\
\hline Montipora monasteriata (Forsskål, 1775) & $\mathrm{H}^{\mathrm{s}}$ & IP & $\bullet$ \\
\hline Montipora nodosa (Dana, 1846) & $\mathrm{H}^{\mathrm{s}}$ & IP & $\bullet$ \\
\hline Montipora peltiformis Bernard, 1897 & $\mathrm{H}^{\mathrm{s}}$ & IP & $\bullet$ \\
\hline Montipora spongodes Bernard, 1897 & $\mathrm{H}^{\mathrm{s}}$ & IP & $\bullet$ \\
\hline Montipora spumosa (Lamarck, 1816) & $\mathrm{H}^{\mathrm{s}}$ & IP & • \\
\hline Montipora tuberculosa (Lamarck, 1816) & $\mathrm{H}^{\mathrm{s}}$ & IP & • \\
\hline Montipora turgescens Bernard, 1897 & $\mathrm{H}^{\mathrm{s}}$ & IP & $\bullet$ \\
\hline Montipora turtlensis Veron \& Wallace, 1984 & $\mathrm{H}^{\mathrm{s}}$ & IWP & \\
\hline Montipora undata Bernard, 1897 & $\mathrm{H}^{\mathrm{s}}$ & IP & $\bullet$ \\
\hline Montipora venosa (Ehrenberg, 1834) & $\mathrm{H}^{\mathrm{s}}$ & IP & \\
\hline Montipora verrucosa (Lamarck, 1816) & $\mathrm{H}^{\mathrm{s}}$ & IP & • \\
\hline \multicolumn{4}{|l|}{ Family: Agariciidae } \\
\hline Coeloseris mayeri Vaughan, 1918 & $\mathrm{H}^{\mathrm{s}}$ & $\mathrm{IP}$ & • \\
\hline Gardineroseris planulata (Dana, 1846) & $\mathrm{H}^{\mathrm{s}}$ & IP & $\bullet$ \\
\hline Leptoseris explanata Yabe \& Sugiyama, 1941 & $\mathrm{H}^{\mathrm{s}}$ & IP & $\bullet$ \\
\hline Leptoseris foliosa Dinesen, 1980 & $\mathrm{H}^{\mathrm{s}}$ & IWP & \\
\hline Leptoseris hawaiiensis Vaughan, 1907 & $\mathrm{H}^{\mathrm{s}}$ & IP & \\
\hline Leptoseris incrustans (Quelch, 1886) & $\mathrm{H}^{\mathrm{s}}$ & IP & \\
\hline Leptoseris mycetoseroides Wells, 1954 & $\mathrm{H}^{\mathrm{s}}$ & IP & $\bullet$ \\
\hline Leptoseris papyracea (Dana, 1846) & $\mathrm{H}^{\mathrm{s}}$ & IP & \\
\hline Leptoseris scabra Vaughan, 1907 & $\mathrm{H}^{\mathrm{s}}$ & IP & \\
\hline Leptoseris yabei (Pillai \& Scheer, 1976) & $\mathrm{H}^{\mathrm{s}}$ & $\mathrm{IP}$ & $\bullet$ \\
\hline Pachyseris rugosa (Lamarck, 1801) & $\mathrm{H}^{\mathrm{s}}$ & IP & $\bullet$ \\
\hline Pachyseris speciosa (Dana, 1846) & $\mathrm{H}^{\mathrm{s}}$ & IP & $\bullet$ \\
\hline Pavona cactus (Forsskål, 1775) & $\mathrm{H}^{\mathrm{s}}$ & IP & \\
\hline Pavona clavus (Dana, 1846) & $\mathrm{H}^{\mathrm{s}}$ & IP & \\
\hline Pavona decussata (Dana, 1846) & $\mathrm{H}^{\mathrm{s}}$ & IP & $\bullet$ \\
\hline Pavona duerdeni Vaughan, 1907 & $\mathrm{H}^{\mathrm{s}}$ & IP & \\
\hline Pavona explanulata (Lamarck, 1816) & $\mathrm{H}^{\mathrm{s}}$ & IP & $\bullet$ \\
\hline Pavona frondifera (Lamarck, 1816) & $\mathrm{H}^{\mathrm{s}}$ & IP-not Aus/PNG & \\
\hline Pavona maldivensis (Gardiner, 1905) & $\mathrm{H}^{\mathrm{s}}$ & IP & \\
\hline Pavona minuta Wells, 1954 & $\mathrm{H}^{\mathrm{s}}$ & IWP & • \\
\hline Pavona varians Verrill, 1864 & $\mathrm{H}^{\mathrm{s}}$ & IP & • \\
\hline Pavona venosa (Ehrenberg, 1834) & $\mathrm{H}^{\mathrm{s}}$ & IP & $\bullet$ \\
\hline \multicolumn{4}{|l|}{ Family: Astrocoeniidae } \\
\hline Stylocoeniella armata (Ehrenberg, 1834) & $\mathrm{H}^{\mathrm{s}}$ & IP & \\
\hline Stylocoeniella guentheri Bassett-Smith, 1890 & $\mathrm{H}^{\mathrm{s}}$ & IP & $\bullet$ \\
\hline \multicolumn{4}{|l|}{ Family: Caryophylliidae } \\
\hline Heterocyathus aequicostatus Milne Edwards \& Haime, 1848 & $\mathrm{~S}^{\mathrm{S}}$ & IP & $\bullet$ \\
\hline \multicolumn{4}{|l|}{ Family: Dendrophylliidae } \\
\hline Duncanopsammia axifuga (Milne Edwards \& Haime, 1848) & $\mathrm{H}^{\mathrm{s}} / \mathrm{S}^{\mathrm{s}}$ & IWP & - \\
\hline Rhizopsammia verrilli van der Horst, 1922 & $\mathrm{H}^{\mathrm{s}}$ & & $\bullet$ \\
\hline Tubastrea coccinea Lesson, 1829 & $\mathrm{H}^{\mathrm{s}}$ & & $\bullet$ \\
\hline Tubastrea micranthus (Ehrenberg, 1834) & $\mathrm{H}^{\mathrm{s}}$ & & \\
\hline Turbinaria bifrons Brüggemann, 1877 & $\mathrm{H}^{\mathrm{s}}$ & IWP & $\bullet$ \\
\hline
\end{tabular}




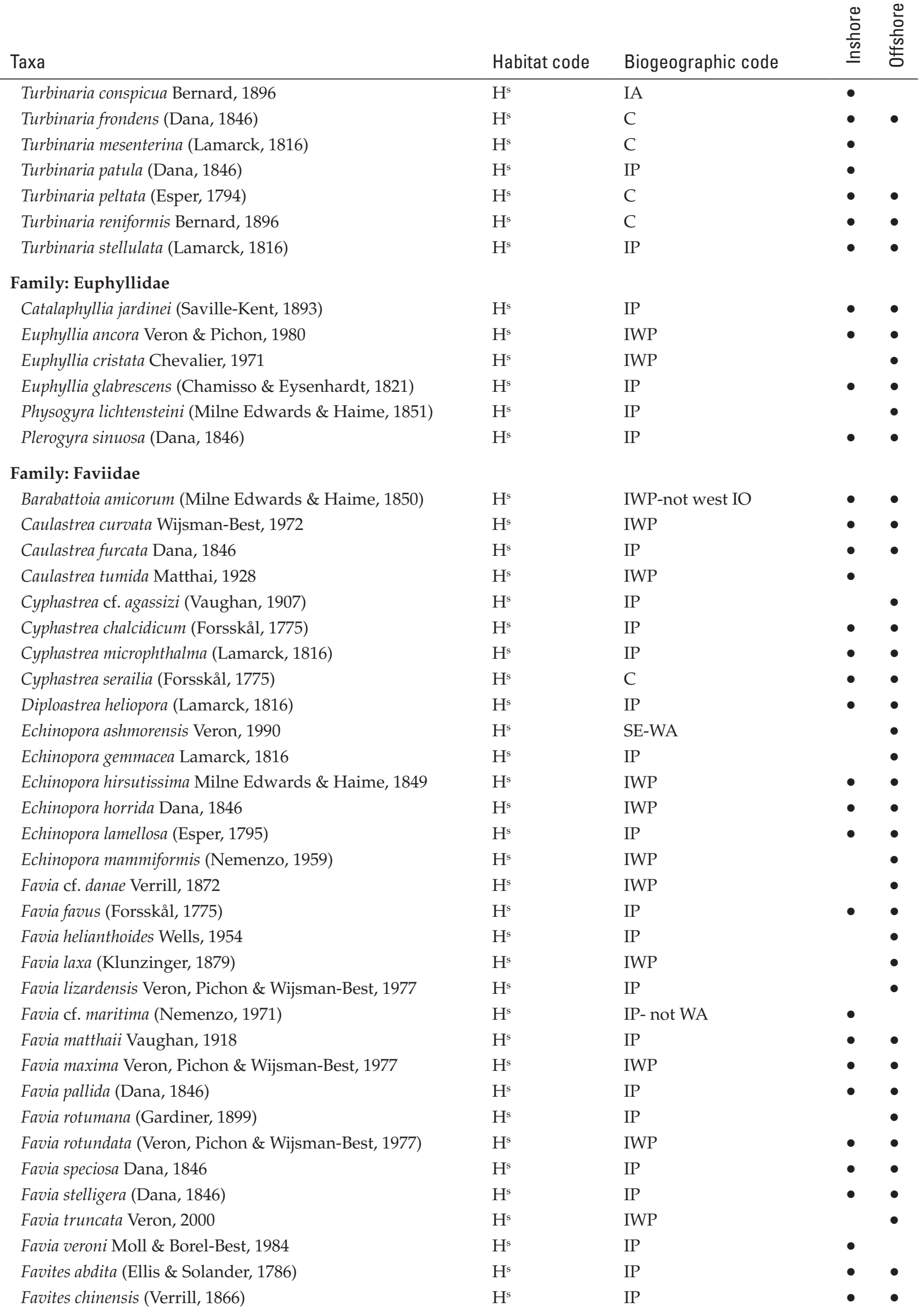




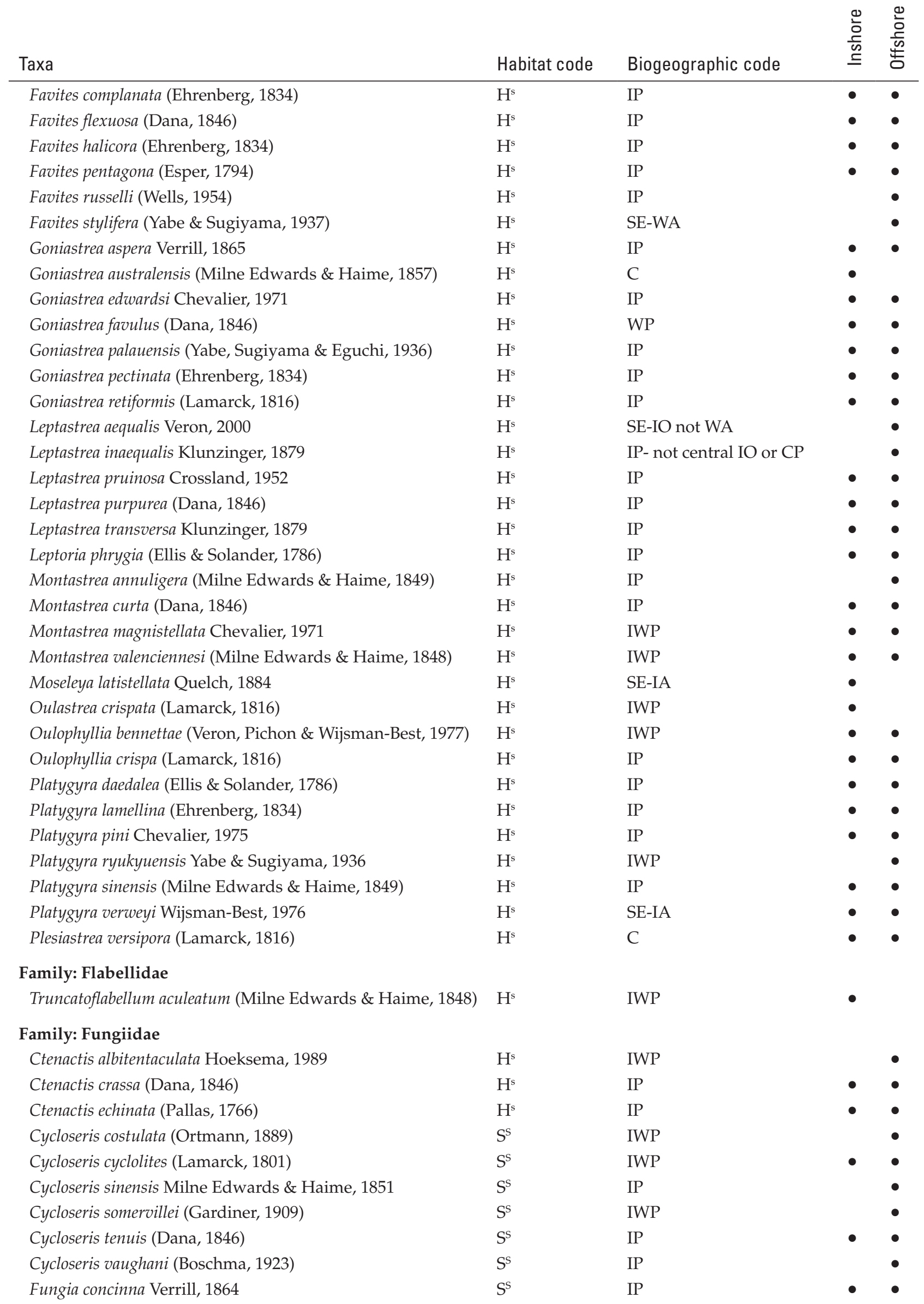




\begin{tabular}{|c|c|c|c|}
\hline Taxa & Habitat code & Biogeographic code & 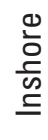 \\
\hline Fungia fungites (Linnaeus, 1758) & $S^{S}$ & IP & $\bullet$ \\
\hline Fungia granulosa Klunzinger, 1879 & $\mathrm{~S}^{\mathrm{S}}$ & IP & \\
\hline Fungia gravis Nemenzo, 1955 & $S^{S}$ & & \\
\hline Fungia horrida Dana, 1846 & $S^{S}$ & IP & $\bullet$ \\
\hline Fungia klunzingeri Döderlein, 1901 & $S^{S}$ & IWP & \\
\hline Fungia cf. moluccensis. Horst, 1919 & $\mathrm{~S}^{\mathrm{S}}$ & IP & \\
\hline Fungia paumotensis Stutchbury, 1833 & $S^{S}$ & IP & \\
\hline Fungia repanda Dana, 1846 & $S^{S}$ & IP & $\bullet$ \\
\hline Fungia scruposa Klunzinger, 1879 & $S^{S}$ & IP & $\bullet$ \\
\hline Fungia scutaria Lamarck, 1801 & $S^{S}$ & IP & $\bullet$ \\
\hline Halomitra pileus (Linnaeus, 1758) & $S^{S}$ & $\mathrm{IP}$ & \\
\hline Heliofungia actiniformis (Quoy \& Gaimard, 1833) & $S^{S}$ & & $\bullet$ \\
\hline Herpolitha limax (Esper, 1797) & $S^{S}$ & IP & $\bullet$ \\
\hline Lithophyllon mokai Hoeksema, 1989 & $\mathrm{H}^{\mathrm{s}}$ & IP & \\
\hline Lithophyllon undulatum Rehberg, 1892 & $\mathrm{H}^{\mathrm{s}}$ & IWP & $\bullet$ \\
\hline Podabacia crustacea (Pallas, 1766) & $\mathrm{H}^{\mathrm{s}}$ & IP & $\bullet$ \\
\hline Polyphyllia talpina (Lamarck, 1801) & $\mathrm{H}^{\mathrm{s}}$ & IP & $\bullet$ \\
\hline Sandalolitha robusta Quelch, 1886 & $\mathrm{H}^{\mathrm{s}}$ & IWP-not west IO & $\bullet$ \\
\hline \multicolumn{4}{|l|}{ Family: Merulinidae } \\
\hline Hydnophora exesa (Pallas, 1766) & $\mathrm{H}^{\mathrm{s}}$ & IP & $\bullet$ \\
\hline Hydnophora microconos (Lamarck, 1816) & $\mathrm{H}^{\mathrm{s}}$ & IP & $\bullet$ \\
\hline Hydnophora pilosa Veron, 1985 & $\mathrm{H}^{\mathrm{s}}$ & IP & $\bullet$ \\
\hline Hydnophora rigida (Dana, 1846) & $\mathrm{H}^{\mathrm{s}}$ & IP & $\bullet$ \\
\hline Merulina ampliata (Ellis \& Solander, 1786) & $\mathrm{H}^{\mathrm{s}}$ & IP & $\bullet$ \\
\hline Merulina scabricula Dana, 1846 & $\mathrm{H}^{\mathrm{s}}$ & IP & \\
\hline Scapophyllia cylindrica Milne Edwards \& Haime, 1848 & $\mathrm{H}^{\mathrm{s}}$ & IP & $\bullet$ \\
\hline \multicolumn{4}{|l|}{ Family: Mussidae } \\
\hline Acanthastrea bowerbanki Milne Edwards \& Haime, 1851 & $\mathrm{H}^{\mathrm{s}}$ & IWP & \\
\hline Acanthastrea brevis Milne Edwards \& Haime, 1849 & $\mathrm{H}^{\mathrm{s}}$ & IWP & \\
\hline Acanthastrea echinata (Dana, 1846) & $\mathrm{H}^{\mathrm{s}}$ & IP & $\bullet$ \\
\hline Acanthastrea hillae Wells, 1955 & $\mathrm{H}^{\mathrm{s}}$ & IWP & $\bullet$ \\
\hline Acanthastrea lordhowensis Veron \& Pichon, 1982 & $\mathrm{H}^{\mathrm{s}}$ & IWP & $\bullet$ \\
\hline Australomussa rowleyensis Veron, 1985 & $\mathrm{H}^{\mathrm{s}}$ & IWP & $\bullet$ \\
\hline Cynarina lacrymalis (Milne Edwards \& Haime, 1848) & $\mathrm{H}^{\mathrm{s}}$ & IP & $\bullet$ \\
\hline Lobophyllia corymbosa (Forsskål, 1775) & $\mathrm{H}^{\mathrm{s}}$ & IP & $\bullet$ \\
\hline Lobophyllia hataii Yabe, Sugiyama \& Eguchi, 1936 & $\mathrm{H}^{\mathrm{s}}$ & IP & \\
\hline Lobophyllia hemprichii (Ehrenberg, 1834) & $\mathrm{H}^{\mathrm{s}}$ & IP & $\bullet$ \\
\hline Scolymia vitiensis Brüggemann, 1877 & $\mathrm{H}^{\mathrm{s}}$ & IP- not WA & $\bullet$ \\
\hline Symphyllia agaricia Milne Edwards \& Haime, 1849 & $\mathrm{H}^{\mathrm{s}}$ & IP & \\
\hline Symphyllia radians Milne Edwards \& Haime, 1849 & $\mathrm{H}^{\mathrm{s}}$ & IP & $\bullet$ \\
\hline Symphyllia recta (Dana, 1846) & $\mathrm{H}^{\mathrm{s}}$ & IP & $\bullet$ \\
\hline Symphyllia valenciennesii Milne Edwards \& Haime, 1849 & $\mathrm{H}^{\mathrm{s}}$ & IP & \\
\hline \multicolumn{4}{|l|}{ Family: Oculinidae } \\
\hline Galaxea astreata (Lamarck, 1816) & $\mathrm{H}^{\mathrm{s}}$ & IP & $\bullet$ \\
\hline Galaxea fascicularis (Linnaeus, 1767) & $\mathrm{H}^{\mathrm{s}}$ & IP & $\bullet$ \\
\hline Galaxea horrescens (Dana, 1846) & $\mathrm{H}^{\mathrm{s}}$ & IP & \\
\hline Galaxea cf. longisepta Fenner \& Veron, 2000 & $\mathrm{H}^{\mathrm{s}}$ & IWP & \\
\hline
\end{tabular}




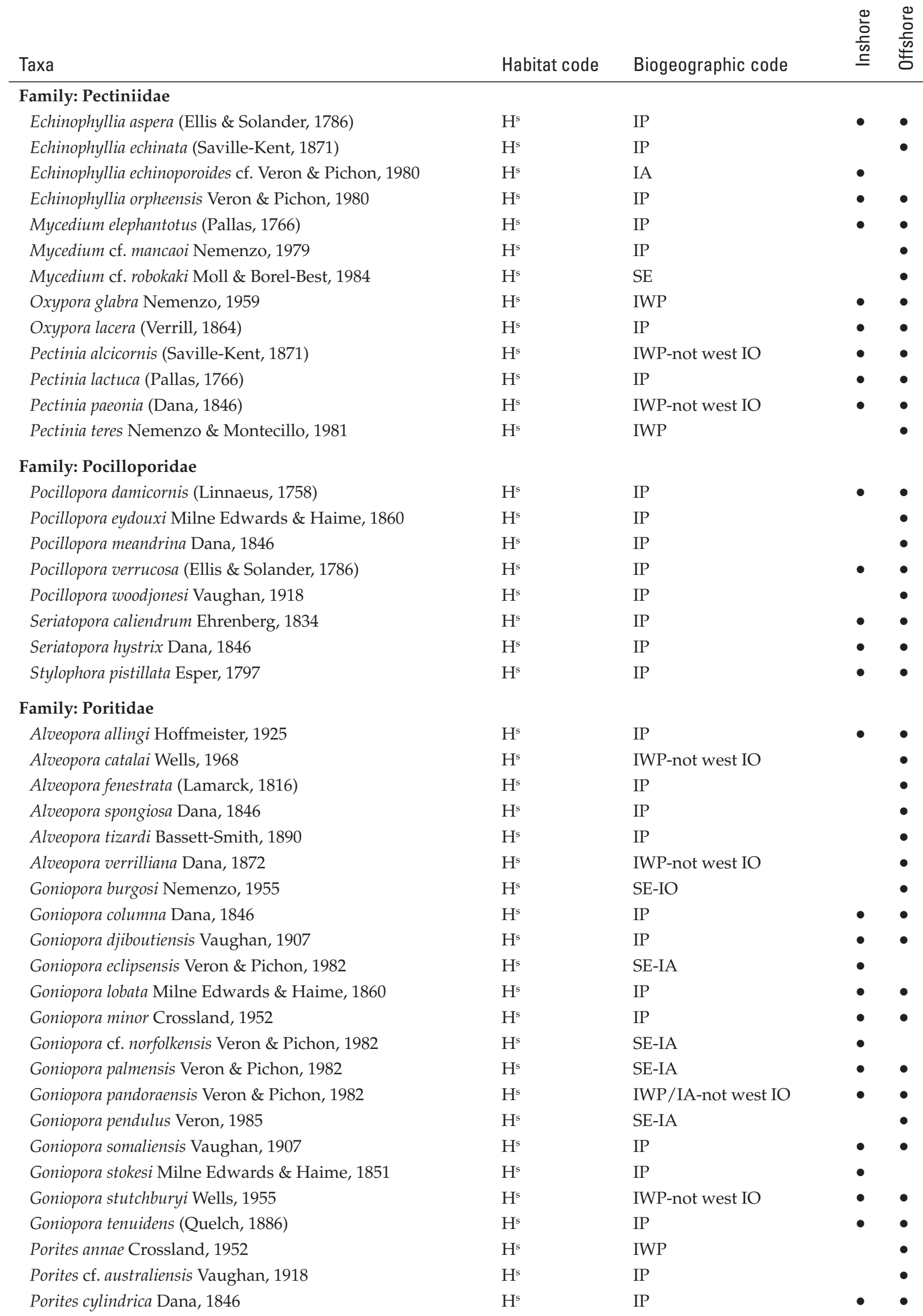




\begin{tabular}{|c|c|c|c|c|}
\hline Taxa & Habitat code & Biogeographic code & 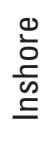 & $\begin{array}{l}\text { d } \\
\frac{0}{5} \\
\frac{0}{4} \\
\end{array}$ \\
\hline Porites eridani Umbgrove, 1940 & $\mathrm{H}^{\mathrm{s}}$ & SE & & $\bullet$ \\
\hline Porites lichen Dana, 1846 & $\mathrm{H}^{\mathrm{s}}$ & $\mathrm{IP}$ & $\bullet$ & $\bullet$ \\
\hline Porites lobata Dana, 1846 & $\mathrm{H}^{\mathrm{s}}$ & IP & $\bullet$ & $\bullet$ \\
\hline Porites lutea Milne Edwards \& Haime, 1851 & $\mathrm{H}^{\mathrm{s}}$ & IP & $\bullet$ & $\bullet$ \\
\hline Porites monticulosa Dana, 1846 & $\mathrm{H}^{\mathrm{s}}$ & IP-not WA or CP & & $\bullet$ \\
\hline Porites murrayensis Vaughan, 1918 & $\mathrm{H}^{\mathrm{s}}$ & IP & & $\bullet$ \\
\hline Porites nigrescens Dana, 1846 & $\mathrm{H}^{\mathrm{s}}$ & IP & • & $\bullet$ \\
\hline Porites rus (Forsskål, 1775) & $\mathrm{H}^{\mathrm{s}}$ & IP & • & $\bullet$ \\
\hline Porites solida (Forsskål, 1775) & $\mathrm{H}^{\mathrm{s}}$ & IP & & $\bullet$ \\
\hline Porites stephensoni Crossland, 1952 & $\mathrm{H}^{\mathrm{s}}$ & IP & $\bullet$ & $\bullet$ \\
\hline Porites vaughani Crossland, 1952 & $\mathrm{H}^{\mathrm{s}}$ & IWP-not west IO & & $\bullet$ \\
\hline \multicolumn{5}{|l|}{ Family: Siderasteridae } \\
\hline Coscinaraea columna (Dana, 1846) & $\mathrm{H}^{\mathrm{s}}$ & IP & $\bullet$ & $\bullet$ \\
\hline Coscinaraea exesa (Dana, 1846) & $\mathrm{H}^{\mathrm{s}}$ & IP & • & $\bullet$ \\
\hline Coscinaraea cf. wellsi Veron \& Pichon, 1980 & $\mathrm{H}^{\mathrm{s}}$ & IP & & $\bullet$ \\
\hline Psammocora contigua (Esper, 1797) & $\mathrm{H}^{\mathrm{s}}$ & IP & $\bullet$ & $\bullet$ \\
\hline Psammocora digitata Milne Edwards \& Haime, 1851 & $\mathrm{H}^{\mathrm{s}}$ & IP & $\bullet$ & $\bullet$ \\
\hline Psammocora explanulata Horst, 1922 & $\mathrm{H}^{\mathrm{s}}$ & IP & $\bullet$ & $\bullet$ \\
\hline Psammocora haimeana Milne Edwards \& Haime, 1851 & $\mathrm{H}^{\mathrm{s}}$ & IP & $\bullet$ & $\bullet$ \\
\hline Psammocora nierstraszi Horst, 1921 & $\mathrm{H}^{\mathrm{s}}$ & IP & & $\bullet$ \\
\hline Psammocora cf. obtusangula (Lamarck, 1816) & $\mathrm{H}^{\mathrm{s}}$ & IP & & $\bullet$ \\
\hline Psammocora profundacella Gardiner, 1898 & $\mathrm{H}^{\mathrm{s}}$ & IP & • & $\bullet$ \\
\hline Psammocora superficialis Gardiner, 1898 & $\mathrm{H}^{\mathrm{s}}$ & IP & $\bullet$ & $\bullet$ \\
\hline Pseudosiderastrea tayami Yabe \& Sugiyama, 1935 & $\mathrm{H}^{\mathrm{s}}$ & IP & - & \\
\hline \multicolumn{5}{|l|}{ Family: Trachyphylliidae } \\
\hline Trachyphyllia geoffroyi (Audouin, 1826) & $\mathrm{H}^{\mathrm{s}}$ & IWP & $\bullet$ & \\
\hline
\end{tabular}




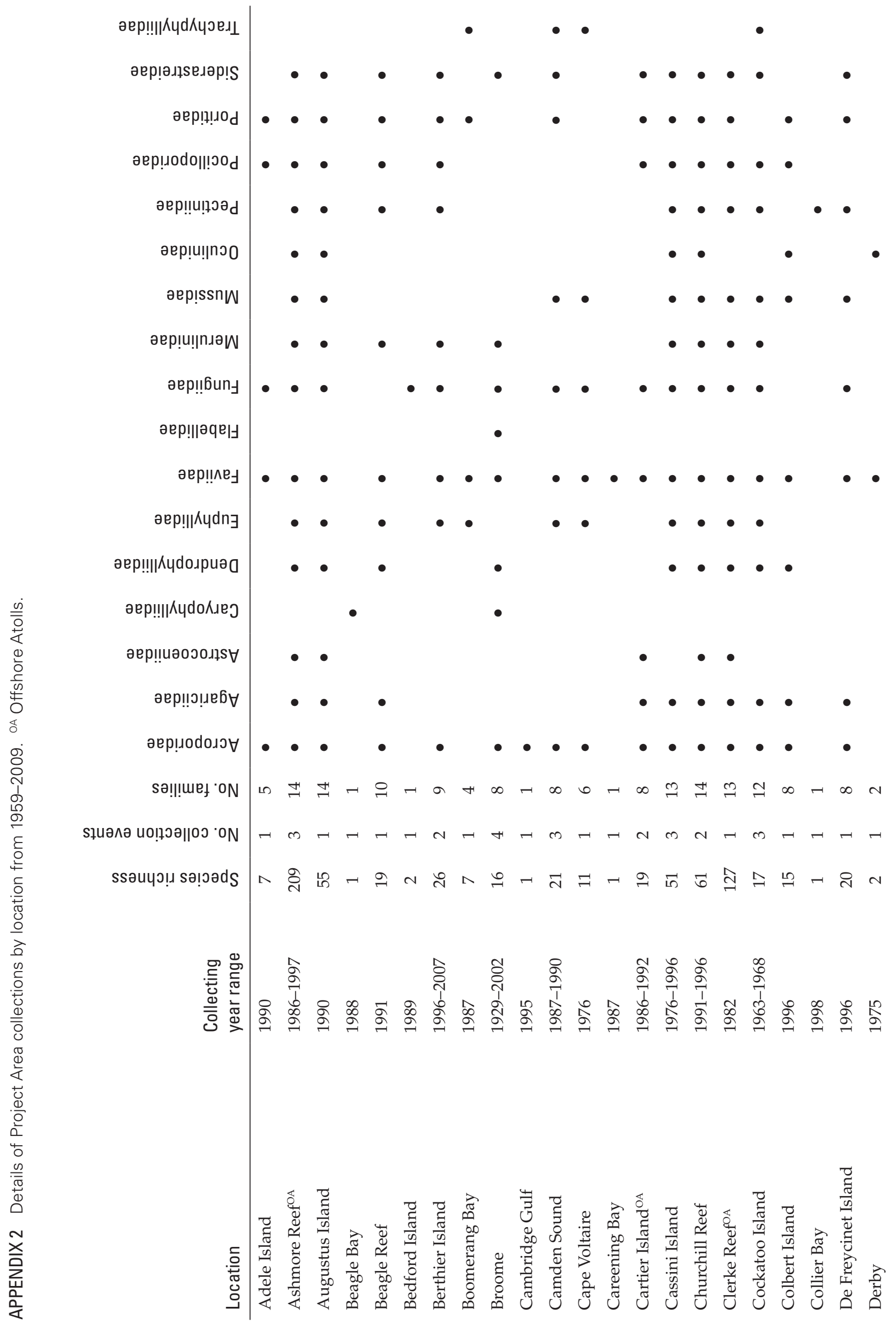




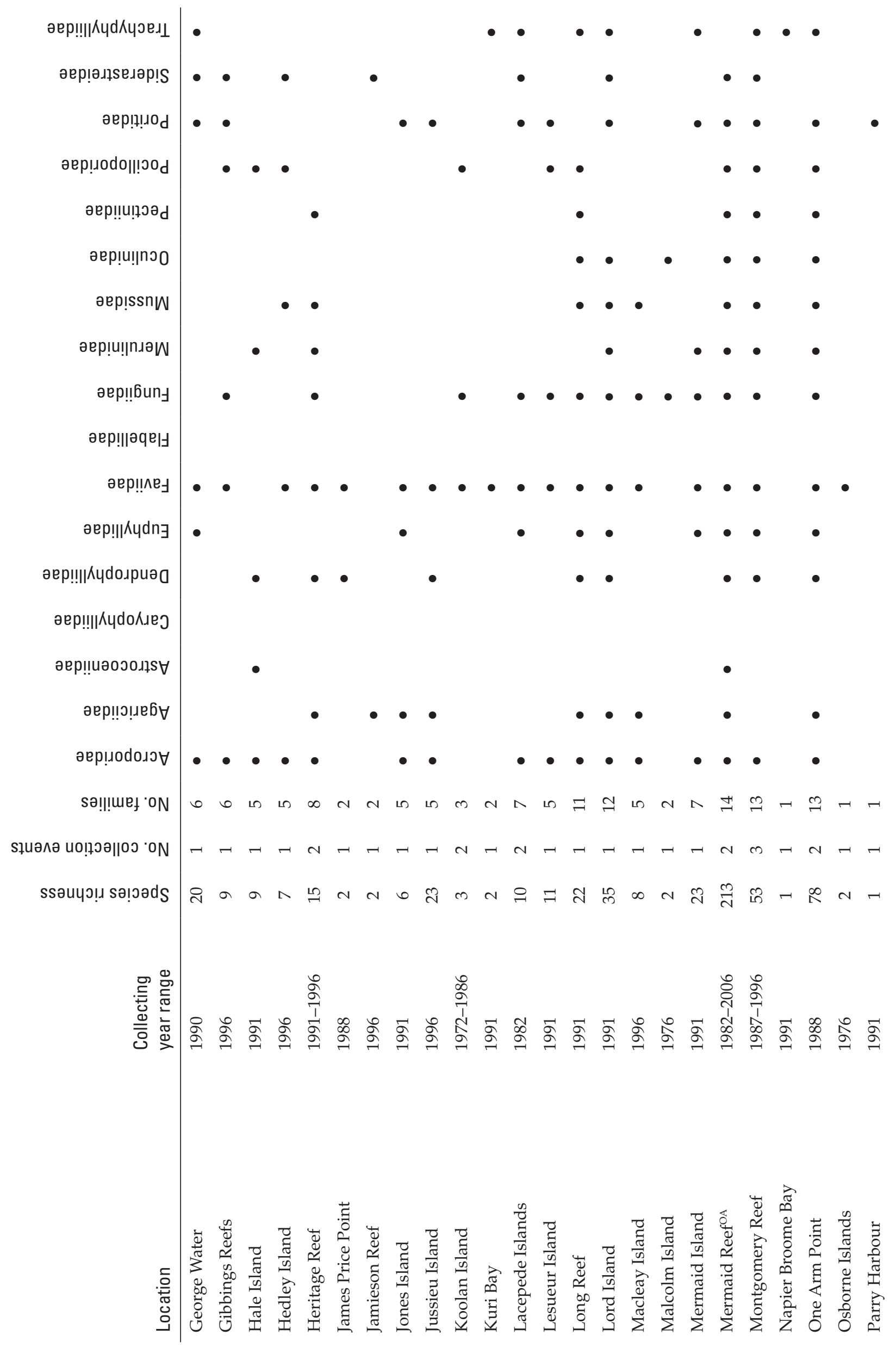




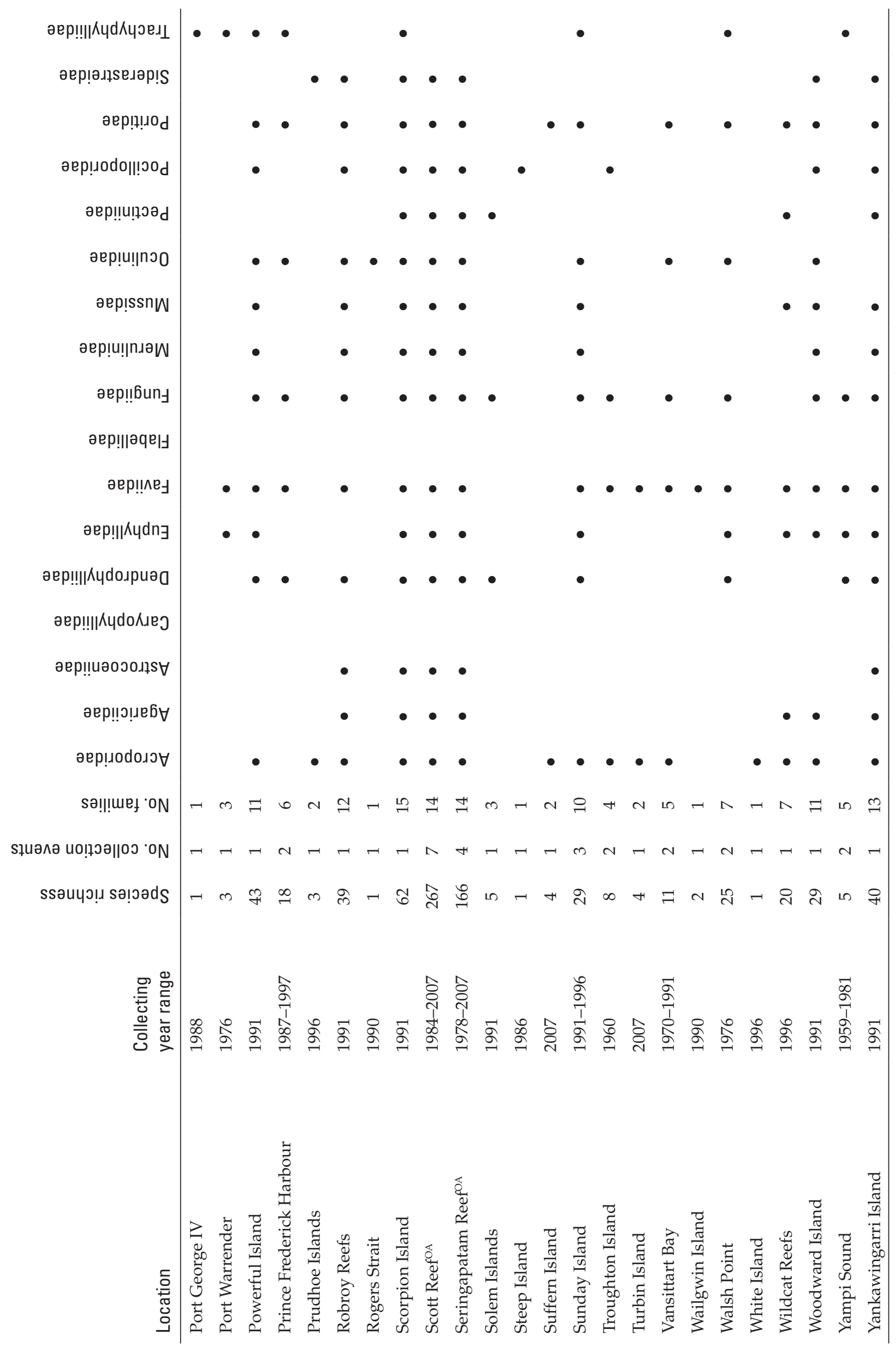

